\title{
Effects of ocean acidification and global warming on reef bioerosion-lessons from a clionaid sponge
}

\author{
Max Wisshak ${ }^{1, *}$, Christine H. L. Schönberg ${ }^{2}$, Armin Form ${ }^{3}$, André Freiwald ${ }^{1}$ \\ ${ }^{1}$ Senckenberg am Meer, Marine Research Department, 26382 Wilhelmshaven, Germany \\ ${ }^{2}$ Australian Institute of Marine Science (AIMS), University of Western Australia, Crawley, Western Australia 9006, Australia \\ ${ }^{3}$ GEOMAR Helmholtz Centre for Ocean Research, Marine Biogeochemistry, 24105 Kiel, Germany
}

\begin{abstract}
Coral reefs are under threat, exerted by a number of interacting effects inherent to the present climate change, including ocean acidification and global warming. Bioerosion drives reef degradation by recycling carbonate skeletal material and is an important but understudied factor in this context. Twelve different combinations of $p \mathrm{CO}_{2}$ and temperature were applied to elucidate the consequences of ocean acidification and global warming on the physiological response and bioerosion rates of the zooxanthellate sponge Cliona orientalis - one of the most abundant and effective bioeroders on the Great Barrier Reef, Australia. Our results confirm a significant amplification of the sponges' bioerosion capacity with increasing $p \mathrm{CO}_{2}$, which is expressed by more carbonate being chemically dissolved by etching. The health of the sponges and their photosymbionts was not affected by changes in $p \mathrm{CO}_{2}$, in contrast to temperature, which had significant negative impacts at higher levels. However, we could not conclusively explain the relationship between temperature and bioerosion rates, which were slightly reduced at both colder as well as warmer temperatures than ambient. The present findings on the effects of ocean acidification on chemical bioerosion, however, will have significant implications for predicting future reef carbonate budgets, as sponges often contribute the lion's share of internal bioerosion on coral reefs.
\end{abstract}

KEY WORDS: Global change $\cdot$ Carbon dioxide $\cdot$ Temperature $\cdot$ Bioerosion $\cdot$ Cliona orientalis Great Barrier Reef

\section{INTRODUCTION}

The growing human population has severe environmental impacts, often summarised under the term 'global change'. In the marine realm, 2 of the main forces causing significant changes are global warming and ocean acidification (OA), both largely driven by the burning of fossil fuels that has led to the current dramatic rise in carbon dioxide partial pressure $\left(p \mathrm{CO}_{2}\right)$ and increasing sea surface temperatures. Coral reefs are perceived as one of the main victims of this development, where warming and OA potentially have significant consequences for the calcium carbonate $\left(\mathrm{CaCO}_{3}\right)$ balance (Hoegh-Guldberg et al. 2007, Erez et al. 2011, Veron 2011). While the com-

*Email: max.wisshak@senckenberg.de plex effects of temperature may both promote or interfere with coral calcification (Reynaud et al. 2003, Rodolfo-Metalpa et al. 2011), OA was demonstrated to have chiefly negative effects on health, reproduction, growth, and survival of corals and other marine biota (De'ath et al. 2009, Kroeker et al. 2010, 2013, Andersson et al. 2011, Pandolfi et al. 2011). Nevertheless, some organisms and processes appear to benefit in a high- $\mathrm{CO}_{2}$ world, as evidenced for instance by greater cover of non-calcareous macrophytes and the massive coral Porites - but also a significant increase of internal macrobioerosion within the latter species at a Papua New Guinean coral reef with a naturally reduced $\mathrm{pH}$ (Fabricius et al. 2011). Bioerosion is a key process in the carbonate budget

() The authors 2013. Open Access under Creative Commons by Attribution Licence. Use, distribution and reproduction are unrestricted. Authors and original publication must be credited. 
of coral reefs, yet it is understudied. It acts at various scales and is performed by a multitude of organisms encompassing chemical and/or mechanical means during superficial grazing, attachment, or internal micro- and macrobioerosion (e.g. Wisshak \& Tapanila 2008, Tribollet \& Golubic 2011, Tribollet et al. 2011). While healthy reefs maintain a positive budget or at least equilibrium between calcification and bioerosion, certain environmental conditions can tip the scale towards erosion (e.g. Glynn 1997, Perry et al. 2008). Acknowledging the importance of bioerosion for structuring coral reefs, recent experimental studies have looked at the effects of OA and confirmed an acceleration of bioerosion with increasing $p \mathrm{CO}_{2}$ for 2 principal agents of internal bioerosion: phototrophic microbial euendoliths (Tribollet et al. 2006, 2009, Reyes-Nivia et al. 2013) and bioeroding sponges (Wisshak et al. 2012). These studies considered OA as the sole factor or used fixed scenarios preventing separate evaluation of environmental factors, and we still cannot answer how global warming may support, balance, or counteract increasing rates of reef bioerosion. Different scenarios may be possible for temperature effects on chemical bioerosion (i.e. biogenic dissolution of $\mathrm{CaCO}_{3}$ ), because on the one hand, the speed of a biochemical reaction is directly proportional to temperature (Atkins \& De Paula 2009), but on the other hand, the capacity of physicochemical dissolution of $\mathrm{CaCO}_{3}$ in seawater is negatively proportional to temperature (Mehrbach et al. 1973), possibly counteracting the effects of OA on bioerosion (Wisshak et al. 2012). In the present study, we report observations on sponge bioerosion affected by OA, global warming, and their interactions, resulting from an experiment involving 12 different combinations of temperature and $p \mathrm{CO}_{2}$.

The bioeroding organism chosen for the experiment was Cliona orientalis Thiele, 1900, a dominant and rapidly bioeroding, zooxanthellate sponge and member of the 'Cliona viridis species complex' which is ubiquitous on tropical coral reefs worldwide (Schönberg 2000, 2002a, b, van Soest et al. 2013). C. orientalis may reach several square metres in colony surface area at over $1 \mathrm{~cm}$ of penetration depth, and routinely invades and kills live corals (Schönberg 2000, Schönberg \& Wilkinson 2001). C. orientalis was reported to survive and increase in abundance after a heating event causing severe coral bleaching (Schönberg \& Ortiz 2009), and it is particularly robust and overall very suitable for experimental studies (Schönberg \& Wilkinson 2001, Schönberg 2002b, Wisshak et al. 2012). C. orientalis erodes by biochemical dissolution, leading to the formation of cup-shaped grooves and the mechanical extraction of so-called sponge chips (Schönberg 2008), a very effective mode of penetration resulting in annual bioerosion rates of $>10 \mathrm{~kg} \mathrm{CaCO} \mathrm{m}^{-2}$ of calcareous substrate for this species (Schönberg 2002b). Within the local community of bioeroding sponges at the Great Barrier Reef, C. orientalis is the most abundant species with respect to the infested reef surface area (Schönberg \& Ortiz 2009), and owing to its high rate of bioerosion (Schönberg 2002b), it is also the most destructive one, emphasising the relevance of potential effects of climate change on the bioerosion rate of this species.

\section{MATERIALS AND METHODS}

\section{Sampling and maintenance of Cliona orientalis}

All sampling and experimental procedures were conducted at Orpheus Island Research Station (OIRS), located on Orpheus Island, central Great Barrier Reef, Australia (Fig. 1). The local community of bio-

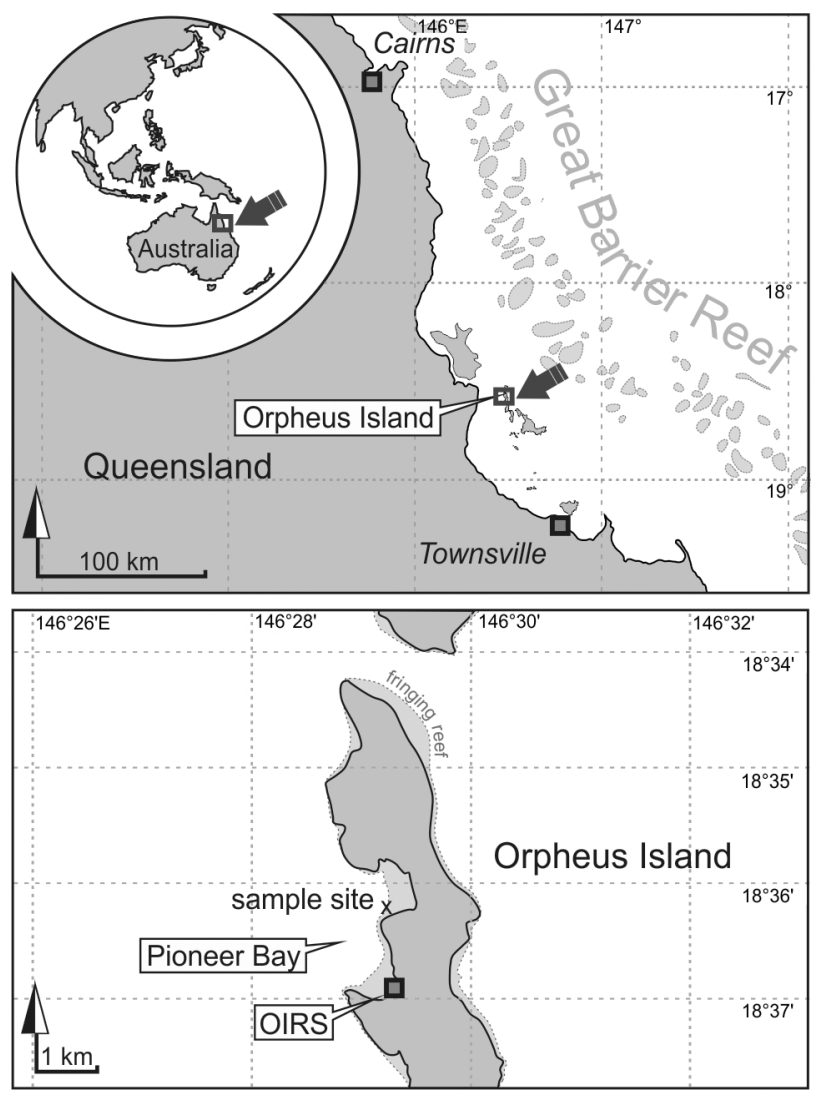

Fig. 1. Location map of Queensland, with Orpheus Island (Palm Island Group) on the central Great Barrier Reef (top). The sample site in Little Pioneer Bay is just north of the Orpheus Island Research Station (OIRS) 
eroding sponges is diverse, comparatively well studied (e.g. Schönberg 2000, 2001), and has recently increased in abundance, possibly as a result of declining reef health related to a heating event resulting in widespread coral death (Schönberg \& Ortiz 2009). At the leeward fringing reef, $C$. orientalis was coresampled in 1 to $3 \mathrm{~m}$ water depth from massive Porites sp. colonies with an air-drill and hole-saw (inner diameter: $30 \mathrm{~mm}$ ), and later trimmed to $25 \mathrm{~mm}$ in length with an air-cutter, so that cores included spongepenetrated material in the upper half and clean coral skeleton below (see Fig. 1D in Wisshak et al. 2012). Individual variation in the amount of sponge tissue in C. orientalis cores was assumed to be insignificant, as evident from the very even erosion pattern in this species (Schönberg \& Shields 2008) and the low standard deviations both for penetration depth as well as sponge biomass measured in 128 sponge-bearing cores taken from 10 different $C$. orientalis colonies in Little Pioneer Bay (see Table 1 in Wisshak et al. 2012). Cores were kept for $4 \mathrm{~d}$ in an outdoor flowthrough tank for recovery, allowing tissue to fully heal before transferring them to a constant-temperature room, offering an acclimatisation period of $24 \mathrm{~h}$. Acclimatisation and experiments were conducted in total darkness to avoid fluctuations in $\mathrm{pH}$ caused by alterations of photosynthesis and respiration due to light/dark cycling and variations in temperature caused by lamps (Wisshak et al. 2012). Directly before and after the experiment, the condition of the sponge cores was documented with digital photography including a colour chart. Photographs were visually examined, assessing images on greyscale and colour, and scoring them as follows: 10: dark chocolate brown, 9: milk chocolate brown (normal before dark adaptation), 8: toffee brown, 7: brownochre (normal after dark adaptation), 6: ochre/yellow-ochre, 5: pale ochre, 4: very pale to translucent, 3: with patches of black disease, likely to recover, 2: most tissue black, but with small portions alive, unlikely to recover, 1: recently dead, black with white film, 0: dead, black, tissue mostly disintegrated. Thus we recorded paling when symbionts were shifted into deeper tissue layers, a process which is affected by light changes, but also by stress and other discolouration (Schönberg \& Suwa 2007), with special attention given to tissue death. The photosymbiosis between the sponge and its dinoflagellate symbionts was assumed to be vital to the sponges' health and physiological functions (e.g. Rosell 1993, Weisz et al. 2010, Hill \& Hill 2012), and photosynthetic parameters were monitored in the dark-adapted samples at the beginning and at the end of the experiment, using pulse-amplitude modulated fluorometry (PAM; Maxi-iPAM, Walz). Photosynthetic efficiency or quantum yield $F_{\mathrm{v}} / F_{\mathrm{m}}$ (ratio of variable to maximum photosynthetic fluorescence) provided a proxy for the health of the symbionts, while baseline photosynthetic fluorescence $F_{0}$ was used as a proxy for chlorophyll concentration, allowing us to recognise whether symbionts were shifted deeper into the sponge cores, which can be a reaction to stress (e.g. Schönberg \& Suwa 2007).

\section{Experimental setup}

All experiments were performed under constant conditions under which the sponge-bearing cores were subjected to different standardised measurements and sampling protocols in a semi-closed system (Fig. 2). To establish consistent water quality and properties throughout the experiment, ambient seawater was filtered to $5 \mu \mathrm{m}$ (thereby retaining picoplankton $<3 \mu \mathrm{m}$ as the main source of nutrition, see e.g. Lynch \& Phlips 2000), and stored in a 6001 reservoir tank connected to a pump and UV unit. Stable experimental temperatures were achieved through climate control of the entire room.

A series of 4 independent $72 \mathrm{~h}$ experiments were run at $\sim 22^{\circ} \mathrm{C}$ (colder than ambient), $\sim 25^{\circ} \mathrm{C}$ (ambient), $\sim 28^{\circ} \mathrm{C}$ (warmer than ambient), and $\sim 31^{\circ} \mathrm{C}$ (stress temperature). Each set of temperatures was run against 3 levels of $p \mathrm{CO}_{2}$ (present-day: ca. $400 \mu \mathrm{atm}$, moderately elevated: ca. $750 \mu \mathrm{atm}$, and strongly elevated: ca. $1700 \mu \mathrm{atm})$, resulting in a treatment matrix with 12 different combinations of temperature and $\mathrm{pCO}_{2}$. The different $p \mathrm{CO}_{2}$ levels were achieved by perturbation with gases specifically mixed with Digamix 5KA 36A/9 pumps on M755-1.2 consoles (H. Wösthoff) using food-grade $\mathrm{CO}_{2}$ and compressed air with ambient $p \mathrm{CO}_{2}$, and only compressed air for the present-day $p \mathrm{CO}_{2}$.

Each treatment included 4 replicate bioreactors (graded 31 beakers), each with 8 sponge-bearing cores sitting on a tethered plastic grid in an aliquot of 2.51 of pre-filtered seawater taken from the reservoir tank. Since donor effects can be caused by genetic differences of the sampled sponges (Maldonado et al. 2008), we attempted the best possible spread of donor diversity per bioreactor, with cores from at least 6 specimens per set. Due to sampling restrictions, we were unable to include true controls (clean coral cores), but we had demonstrated earlier that over such a short period of time, potential abiotic chemical dissolution of the substrate or possible bio- 

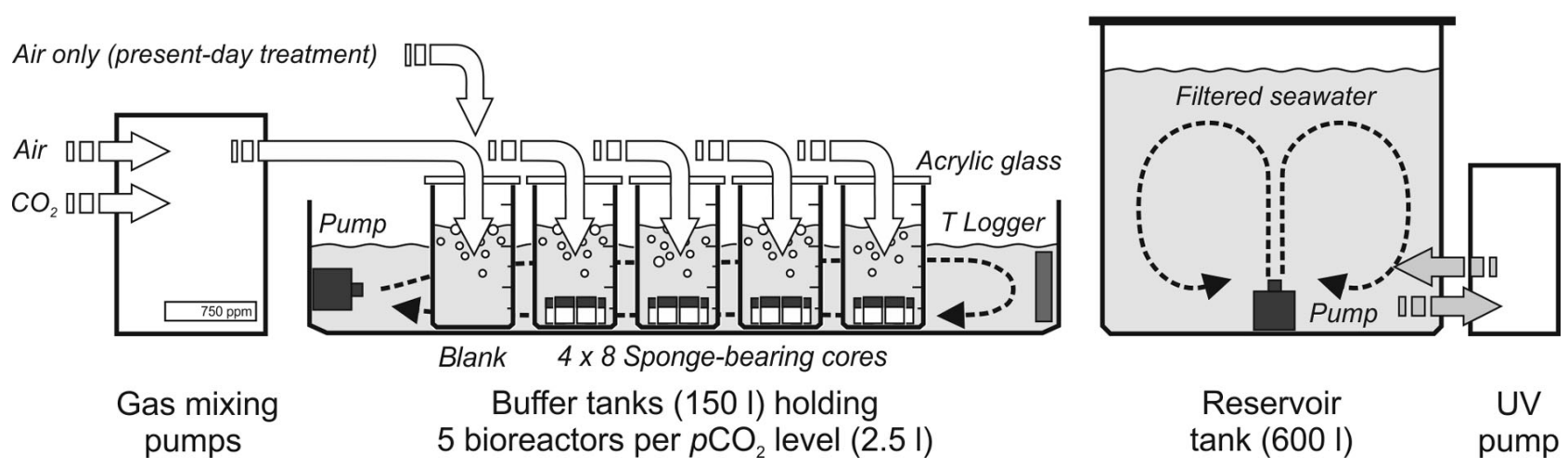

Fig. 2. Setup of experimental system situated in a constant temperature room at Orpheus Island Research Station with individual semi-closed bioreactors (4 replicates per treatment level), carrying 8 sponge-bearing cores each, and 1 bioreactor with seawater only for monitoring purposes, all situated in a larger tank to maintain the respective treatment temperature. The moderately and strongly elevated $p \mathrm{CO}_{2}$ levels were adjusted by perturbation with specifically mixed gases; for the present-day scenario, compressed air was used. Pre-filtered seawater for all treatments was taken from an aerated $600 \mathrm{l}$ reservoir tank connected to a pump and UV unit

erosion by microendoliths remains negligible, even under strongly elevated $p \mathrm{CO}_{2}$ (Wisshak et al. 2012). However, in each treatment, one additional bioreactor with seawater only (blank) served the purpose of monitoring the water chemistry. The temperature in the bioreactors was kept very stable by placing them into $150 \mathrm{l}$ temperature buffer tubs with water adjusted to the constant room temperature. Uniform perturbation per bioreactor proceeded via a flow controller that pumped the gas mixes into the bioreactors at fixed, equal rate per bioreactor, and inert silicon tubing was used in order to prevent stress potentially exerted by plasticisers. The constant perturbation effectively resulted in mixing that prevented the water from becoming dysoxic. A lid covered each bioreactor in order to minimise evaporation and stabilise the $p \mathrm{CO}_{2}$ in the headspace filled with the gas mixture. Humidifying the gas flow in gas-wash bottles filled with de-ionised water further reduced risk of evaporation, which was found to be negligible at $0.2 \pm 0.1 \% \mathrm{~d}^{-1}$ on average $(\mathrm{n}=60)$.

The $72 \mathrm{~h}$ exposure period in potentially stressful conditions inherent to laboratory experiments or crowded aquaria (Osinga et al. 1999) is well within the tolerance limits of Cliona orientalis. We tested our experimental setup in an additional $5 \mathrm{~d}$ experimental run at ambient temperature $\left(25^{\circ} \mathrm{C}\right)$ and present-day $p \mathrm{CO}_{2}$. Daily carbonate system assessments indicated that all sponges continuously bioeroded and survived with few if any stress symptoms. In addition, after the series of $p \mathrm{CO}_{2} \times$ temperature treatments, all surviving sponges were transferred back into an outdoor flow-through system and fully recovered.

\section{Carbonate system parameters}

As a basis for an accurate assessment of the amount of $\mathrm{CaCO}_{3}$ dissolved by Cliona orientalis during the experiment, the seawater carbonate system and the variables characterising or controlling this system were closely monitored (equilibria between aqueous carbon dioxide $\mathrm{CO}_{2 \mathrm{aq}}$, bicarbonate $\mathrm{HCO}_{3}{ }^{-}$, and carbonate ions $\mathrm{CO}_{3}{ }^{2-}$; see Zeebe \& Wolf-Gladrow 2001 for a review). This comprised measurements of the dissolved inorganic carbon (DIC), total alkalinity (TA), $\mathrm{pH}$, temperature, salinity, and dissolved inorganic nutrients. Based on these variables, the remaining carbonate system parameters, as well as the dissolution of carbonate, were quantified (see Table 1).

During the experiment, temperature was recorded in 5 min intervals with Starmon Mini highresolution loggers (Star Oddi; accuracy: $\pm 0.02^{\circ} \mathrm{C}$ ). Water samples were taken and sterile-filtered with $0.2 \mu \mathrm{m}$ PES filters at the start and end of the experiment. Samples for DIC and TA were treated with $0.02 \mathrm{vol} \%$ saturated $\mathrm{HgCl}_{2}$ solution to arrest biological activity, whereas samples for nutrient analyses were left untreated, but stored refrigerated and in the dark. Before water sampling, salinity was measured on the PSS scale using a SevenGo DUO meter (Mettler-Toledo) equipped with an InLab 738-ISM conductivity probe calibrated

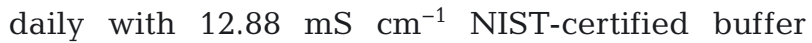
solution. The relative order and timing of all procedures was kept constant over the course of the experiments to avoid natural diurnal variation (Wisshak et al. 2012). 
Prior to chemical analyses, $\mathrm{pH}$ of the water samples was quantified on the total scale using a flatmembrane glass electrode (6.0256.100; Deutsche Metrohm) calibrated against seawater standards of known pH to match ionic strength between samples and buffer solutions. Nitrate, nitrite, and phosphate were evaluated photometrically (U-2000; Hitachi) according to standard methods described by Hansen $\&$ Koroleff (1999) with precision levels of $\pm 0.5, \pm 0.02$, and $\pm 0.05 \mu \mathrm{mol} \mathrm{l}^{-1}$, respectively; ammonium was quantified fluorometrically (SFM 25; Kontron Instruments) according to Holmes et al. (1998) to $\pm 0.08 \mu \mathrm{mol} \mathrm{l}^{-1}$. TA was determined in duplicate, using potentiometric open-cell titration following Dickson et al. (2003). Seawater was weighed (1416B MP8-1; Sartorius) and titrated with $0.005 \mathrm{~N} \mathrm{HCl}$ in an automatic titrator (Titrando 808; Deutsche Metrohm); the average precision between duplicate water samples was $\leq 4 \mu \mathrm{mol} \mathrm{kg}^{-1}$. DIC was measured photochemically following Stoll et al. (2001) using an automated segmented flow analyser (QuAAtro; Bran+Luebbe) equipped with an autosampler $\left( \pm 5 \mu \mathrm{mol} \mathrm{kg}^{-1}\right.$ precision). Both TA and DIC were calibrated with certified seawater reference material (CRM standards supplied by Andrew Dickson, Scripps Institution of Oceanography).

The carbonate system was computed from the obtained temperature, salinity, TA, and $\mathrm{pH}$ using the CO2SYS program (EXCEL macro v. 2.1; Pierrot et al. 2006) with dissociation constants for carbonic acid from Mehrbach et al. (1973) as refit by Dickson \& Millero (1987) and the $\mathrm{KSO}_{4}$ dissociation constant from Dickson (1990). TA and $\mathrm{pH}$ were chosen for the carbonate system calculations in order to avoid inconsistencies in carbonate chemistry potentially affected from calculations by DIC and TA (Hoppe et al. 2012). Moreover, as a control of the whole procedure, the measured $\mathrm{pH}$ values were compared with calculated $\mathrm{pH}$ values (via DIC and TA) and found to differ by only $1.3 \pm 1.6 \%$ on average $(n=108)$.

\section{Assessment of bioerosion rates}

Carbonate dissolution (mg bioreactor ${ }^{-1}$ ) was computed by adapting the alkalinity anomaly technique (Smith \& Key 1975, Chisholm \& Gattuso 1991) from the change in total alkalinity $\Delta \mathrm{TA}$ during the $72 \mathrm{~h}$ of incubation, involving a correction for nitrogen nutrients and phosphate according to Jacques \& Pilson (1980), and using the TA definition of Dickson et al. (2003) (Eq. 1).

$$
\begin{aligned}
\Delta \mathrm{CaCO}_{3}=0.5 & \times\left[\Delta \mathrm{TA}+\Delta \mathrm{PO}_{4}-\Delta \mathrm{NH}_{4}+\Delta\left(\mathrm{NO}_{3}+\mathrm{NO}_{2}\right)\right] \\
& \times 100 \times \mathrm{V}_{\mathrm{sw}} \times \rho_{\mathrm{sw}} / 10^{3}
\end{aligned}
$$

The factor 0.5 reflects the 2:1 relationship between the increase of TA during carbonate dissolution, the multiplier 100 is the molecular mass of $\mathrm{CaCO}_{3}, \mathrm{~V}_{\mathrm{sw}}$ the seawater volume per bioreactor (l), $\rho_{\mathrm{SW}}$ the density of seawater $\left(\mathrm{kg} \mathrm{l}^{-1}\right)$ as a function of temperature and salinity calculated with $\mathrm{R}$ using the package 'SeaCarb' version 2.4 (www.cran.r-project.org/ package=seacarb), and the divider $10^{3}$ converts to the weight unit milligrams.

Evaluation of bioerosion in the $31^{\circ} \mathrm{C}$ treatment was complicated by cases of sponge mortality in 5 out of the 12 bioreactors. The affected sponge tissue turned black, fouling the water and making it more viscous and impossible to filter, thus disabling accurate measurements for carbonate system calculationstherefore data from these bioreactors were excluded from all analyses except for a health assessment. The remaining 7 bioreactors in the $31^{\circ} \mathrm{C}$ treatment yielded high nutrient concentrations at the end of the experiment, with ammonium levels above the threshold for accurate determination (dilution factor $>8$ ). In order to allow adequate correction for nutrients, a conservative estimation of $100 \mu \mathrm{mol} \mathrm{l}^{-1}$ was applied, i.e. a level just above the highest values of ammonium with measurements within the threshold of accurate determination.

Dissolved $\mathrm{CaCO}_{3}$ was then converted to chemical bioerosion rates as $\mathrm{kg} \mathrm{m}^{-2} \mathrm{yr}^{-1}$ by relating the value to the combined sponge tissue surface area of the 8 cores in each bioreactor. Core-sampling generated new surface with feeding apertures, i.e. the sponge was not only supported by the upper circle of original surface, but also by a ring of healed surface around the sides of the cores. As bioerosion underneath this ring-shaped surface area acted on skeleton also underneath the upper surface area, we included only half of this surface into the reference unit in order not to underestimate bioerosion rates. Ring surface area was calculated using the mean tissue penetration depth of $1.32 \pm 0.14 \mathrm{~cm}$, which was determined from $\mathrm{min} / \mathrm{max}$ measurements in 128 sponge-bearing cores taken from 10 different Cliona orientalis colonies in Little Pioneer Bay.

\section{Statistical analyses}

All statistical calculations used means per bioreactor, which represented the replicate level. Despite running the temperature treatments in a temporal se- 
quence, they were regarded as independent, because each time the experiment was adjusted to a new temperature and new sponge cores were used. Mortality occurred in the $31^{\circ} \mathrm{C}$ stress treatment, which resulted in the removal of 5 replicates (bioreactors) in the respective datasets relating to photosynthesis parameters and bioerosion, but 'sponge health' remained fully replicated, because 'death' was part of the health assessment and a result. Increased variation of response values in the extreme treatments also meant that heteroscedasticity was common, and some other assumptions such as normal distribution were occasionally violated as well, which could not always be removed by transformation. Simple non-parametric Kruskal-Wallis tests allowed for neither the recognition of interaction effects nor for post hoc analysis at treatment level. Therefore, we looked for general differences in 5 separate, non-parametric permutational multivariate analysis of variance (PERMANOVA) models calculated in the software Primer 6 and PERMANOVA (Anderson 2005) based on resemblance matrices with Euclidean distance, with 9999 permutations of residuals under a reduced model and with Type III sums of squares (Anderson et al. 2008; models for 'health score', ' $F_{\mathrm{v}} / F_{\mathrm{m}}{ }^{\prime},{ }^{\prime} F_{0}{ }^{\prime}$ ', 'bioerosion rate', and ' $\left.\Delta \mathrm{NH}_{4}{ }^{\prime}\right)$. The experimental factors were entered as fixed effects $\left(p \mathrm{CO}_{2}\right.$ with 3 levels: presentday, moderately elevated, and strongly elevated; temperature with 4 levels: $22,25,28$, and $31^{\circ} \mathrm{C}$ ). Significant results were followed up with PERMANOVA pairwise comparisons. Evaluations of 'health score', ' $F_{\mathrm{v}} / F_{\mathrm{m}}$ ', and ' $F_{0}$ ' partly depended on chlorophyll concentrations in the surface layer of the sponge. They slightly differed between sponge individuals and also were slightly affected by the acclimatisation to constant dark (see Fig. 4 for differences comparing 'before' with 'after' values employing Wilcoxon signed rank tests performed in SPSS 19, IBM). Therefore, these parameters were statistically tested in PERMANOVA as $\%$ of the originally measured value. We then checked relationships between treatments and response values in multiple linear regressions in SPSS. While this was used to answer the central cause-effect query, we also displayed results of additional simple linear regressions to obtain more detailed information on causes and responses and to provide equations for individual settings, e.g. for modelling purposes. The linear regressions may also be useful, because the relationship between 'bioerosion rate' and temperature remained unclear, and at the same time a weak interaction effect was found between temperature and $p \mathrm{CO}_{2}$. Therefore, for 'bioerosion rate', it is more accurate to regard the results for subsets of data than for the multiple linear regression. Slope equations resulting from regressions led to predictions for bioerosion under future conditions (SigmaPlot 12; Systat).

\section{RESULTS}

\section{General physiological responses}

Physiological responses not directly related to bioerosion were monitored for Cliona orientalis: health of the sponge cores and their photosymbionts by visual assessment and by PAM, mortality, recovery, and quantification of dissolved nutrients in the culture water (Figs. $3 \& 4$, Table 1). An overall slight paling of sponge cores was observed after $1 \mathrm{~d}$ in darkness for acclimatisation (cf. Fig. 3a \& 3d). While sponges in the $22^{\circ} \mathrm{C}$ treatment retained their healthy appearance, paling increased with higher temperatures, and $F_{0}$ decreased (Fig. 3d), suggesting that gradually more zooxanthellae were moved away from the surface and deeper into the sponge body. A number of dead or partially dead cores occurred in the $31^{\circ} \mathrm{C}$ stress temperature treatment (Fig. 3c), which was the only situation in which photosynthetic efficiency was also slightly lowered (Fig. 4f). Visual health score and photosynthetic parameters decreased between 'before' and 'after' the experiment (Fig. 3d-f). However, these responses only differed with and were only correlated to temperature increase, not to increased $p \mathrm{CO}_{2}$ (Table 2; and Tables $\mathrm{S} 1 \& \mathrm{~S} 2$ in the Supplement at www.int-res.com/articles/suppl/b019 p111_supp.pdf). Thus no negative effect could be attributed to elevated $p \mathrm{CO}_{2}$, but it may have reduced the temperature stress, as evidenced by our bar graphs (Fig. $4 \mathrm{c}, \mathrm{f}, \mathrm{i}$ ) and possibly supported by interaction effects near the significance threshold for $F_{\mathrm{v}} / F_{\mathrm{m}}$ and $F_{0}$ (Table 2). All cores fully recovered within a week after being placed back into the outdoor flowthrough tanks (Fig. 3b), except for those that were already dead or nearly dead. Cores with smaller black patches lost the affected tissue but recovered.

Initial levels of all examined nutrients in the filtered culture water were very low at $0.06 \pm 0.11 \mu \mathrm{mol}$ $\mathrm{l}^{-1} \mathrm{NO}_{3}, 0.02 \pm 0.02 \mu \mathrm{mol} \mathrm{l}^{-1} \mathrm{NO}_{2}, 0.04 \pm 0.04 \mu \mathrm{mol} \mathrm{l}{ }^{-1}$

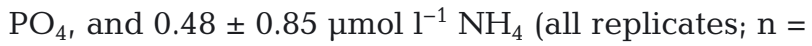
48). At the end of the experiment, the levels for nitrate, nitrite, and phosphate had increased but remained at a low level, with mean values per treatment $<2.60 \mathrm{umol}^{-1}$ (Table 1). In contrast, ammonium levels increased and varied considerably. This increase $\left(\Delta \mathrm{NH}_{4}=10.95 \pm 15.78 \mu \mathrm{mol} \mathrm{l^{-1 }}\right.$ at $22^{\circ} \mathrm{C}_{1} 28.91$ 


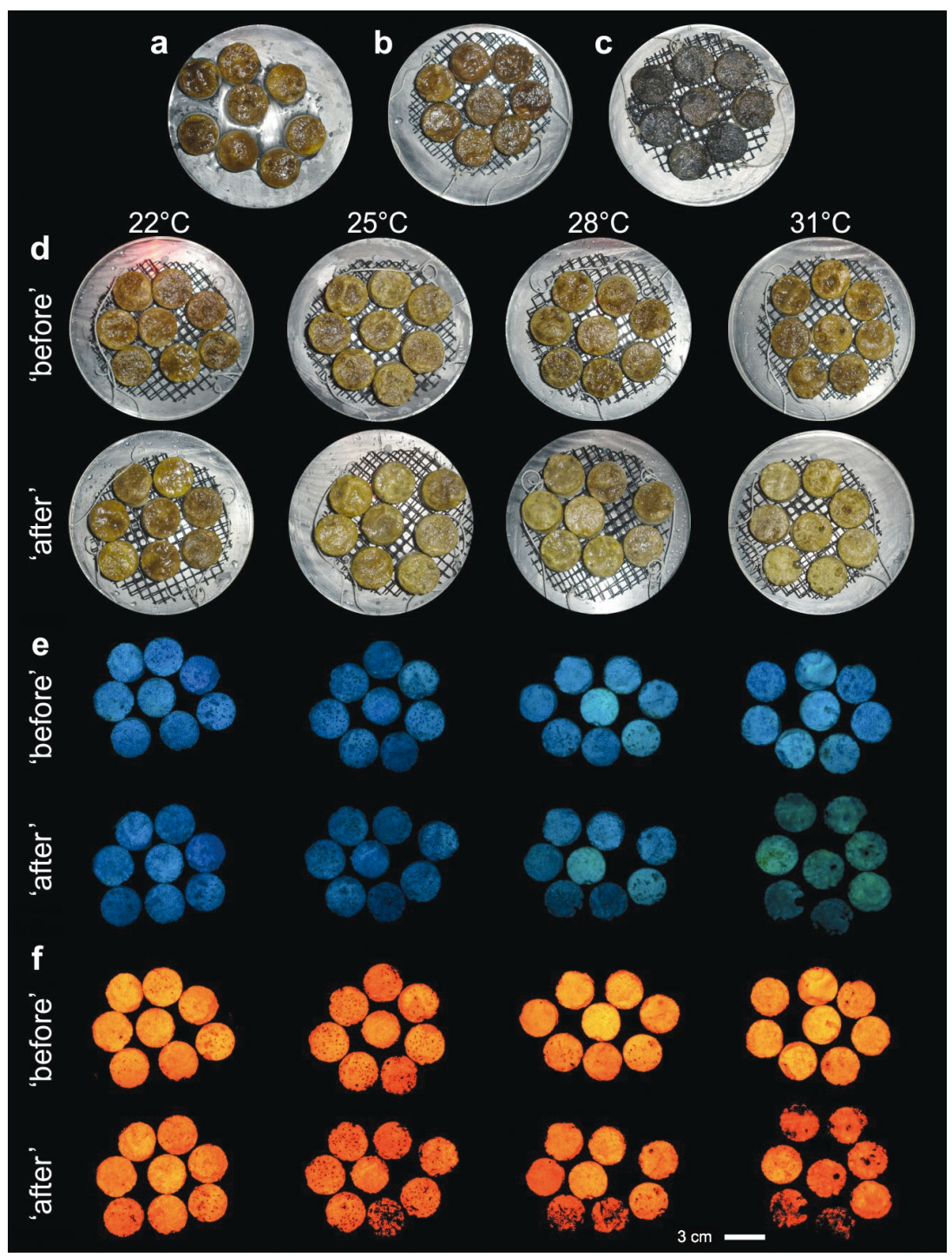

Fig. 3. Monitoring of Cliona orientalis health in symbiosis with zooxanthellae, 'before' (= after acclimatisation) and 'after' the experiment in continuous dark. Only representative figures for different temperature treatments are shown; different $p \mathrm{CO}_{2}$ did not change the appearance within temperature levels. One replicate set of 8 sponge cores each (a) 'before' the experiment, (b) 'after' the experiment and a recovery period of several days in ambient temperature and flow-through conditions, and (c) a set of dead cores from the $31^{\circ} \mathrm{C}$ treatment. Appearance of cores at each temperature level (d) 'before' and 'after' the experiment, and corresponding pulse-amplitude modulated fluorometry (PAM) images illustrating (e) photosynthetic efficiency $F_{\mathrm{v}} / F_{\mathrm{m}}$ and (f) the proxy for chlorophyll concentration $F_{0}$

$\pm 21.70 \mu \mathrm{mol} \mathrm{l} \mathrm{l}^{-1}$ at $25^{\circ} \mathrm{C}, 44.09 \pm 32.97 \mu \mathrm{mol} \mathrm{l} \mathrm{l}^{-1}$ at $28^{\circ} \mathrm{C}$, and a critical level of $98.73 \pm 15.78 \mu \mathrm{mol} \mathrm{l} \mathrm{l}^{-1}$ at $31^{\circ} \mathrm{C}$ ) showed significant correlation with temperature but not with $p \mathrm{CO}_{2}$ (Table 2).

\section{Bioerosion rates}

Bioerosion by Cliona orientalis differed significantly with $p \mathrm{CO}_{2}$ and temperature, and the factors interacted (Figs. 4j \& 5, Table 2). Interaction was most likely caused by the fact that pairwise comparisons between $p \mathrm{CO}_{2}$ levels were always significant, except at $31^{\circ} \mathrm{C}$, where omission of replicates resulted in the loss of support and the failure of finding significances (Table S1). This is expected to be a Type II error of not finding a difference when there should be one, because the plotted data still display the same trend as for the other 3 temperature levels (cf. Fig. 5d and $5 \mathrm{a}-\mathrm{c})$. However, in contrast to a clear linear and directly proportional relationship with $p \mathrm{CO}_{2}$, and consequently a negative correlation with $\mathrm{pH}$ (Fig. 5a-d, 

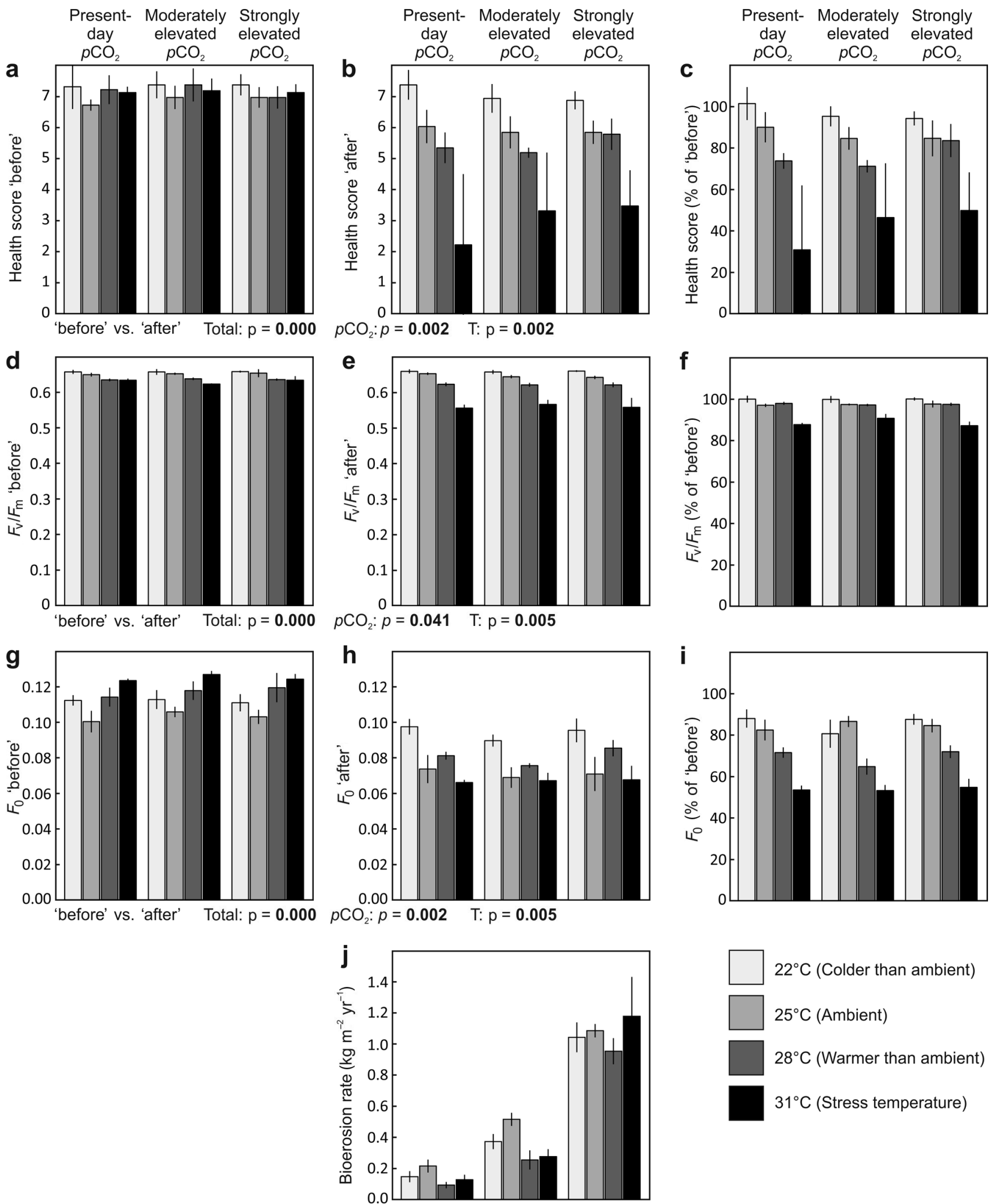

Fig. 4. Means of experimental response values $(a, d, g)$ 'before' (= after acclimatisation period) and (b,e,h) 'after' the experiment, and as (c,f,i) percent of 'before', complemented by (j) the respective rates of chemical bioerosion. Error bars are SD. Displayed significances compare 'before' and 'after' values using a non-parametric Wilcoxon signed-rank test (partial tests separating out the effects of $\mathrm{pCO}_{2}$ and temperature $(\mathrm{T})$ were conducted for ambient conditions of the respective other treatment factor). Significant values in bold. Five replicates for all 'after' and percentage datasets except for the health score were omitted due to mortalities in the $31^{\circ} \mathrm{C}$ treatment series 
Table 1. Experimental settings related to the carbonate system. List of measured (temperature, salinity, $\mathrm{pH}$, mean and $\Delta$ total alkalinity [TA]) and computed carbonate system parameters (dissolved inorganic carbon [DIC], carbon dioxide partial pressure $\left[p \mathrm{CO}_{2}\right]$, hydrogen carbonate $\left[\mathrm{HCO}_{3}\right]$ and carbonate ion $\left[\mathrm{CO}_{3}\right]$ molality, saturation states for aragonite $\left[\Omega_{\mathrm{Ar}}\right]$ and calcite $\left[\Omega_{\mathrm{Ca}}\right]$ ), nutrients (nitrate $\left[\mathrm{NO}_{3}\right]$, nitrite $\left[\mathrm{NO}_{2}\right]$, ammonium $\left[\mathrm{NH}_{4}\right]$, phosphate $\left[\mathrm{PO}_{4}\right]$ ), and rates of chemical sponge bioerosion. Salinity, $\mathrm{pH}$, and TA were measured in duplicate. All values are given as mean $\pm \mathrm{SD}$ among the replicates after $3 \mathrm{~d}$ of exposure

\begin{tabular}{|c|c|c|c|c|}
\hline $\begin{array}{l}\text { Temp. } \\
\text { level }\end{array}$ & Variable & $\begin{array}{l}\text { Present-day } \\
\quad p \mathrm{CO}_{2}\end{array}$ & $\begin{array}{c}\text { Moderately elevated } \\
\qquad \mathrm{CO}_{2}\end{array}$ & $\begin{array}{c}\text { Strongly elevated } \\
\mathrm{pCO}_{2}\end{array}$ \\
\hline $22^{\circ} \mathrm{C}$ & 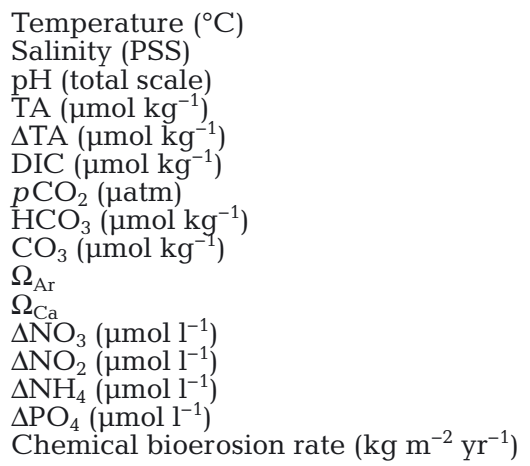 & $\begin{aligned} 21.8 & \pm 0.2 \\
34.2 & \pm 0.0 \\
8.00 & \pm 0.01 \\
2305.3 & \pm 12.6 \\
112.5 & \pm 23.2 \\
2061.2 & \pm 16.8 \\
455.0 & \pm 19.6 \\
1869.4 & \pm 19.1 \\
177.7 & \pm 3.8 \\
2.80 & \pm 0.06 \\
4.29 & \pm 0.09 \\
0.49 & \pm 1.14 \\
0.21 & \pm 0.46 \\
14.31 & \pm 19.33 \\
0.86 & \pm 0.43 \\
0.15 & \pm 0.04\end{aligned}$ & $\begin{aligned} 22.1 & \pm 0.2 \\
34.3 & \pm 0.0 \\
7.80 & \pm 0.01 \\
2384.9 & \pm 10.2 \\
266.8 & \pm 19.2 \\
2227.8 & \pm 13.3 \\
804.6 & \pm 27.3 \\
2076.3 & \pm 14.3 \\
126.8 & \pm 2.3 \\
2.00 & \pm 0.04 \\
3.06 & \pm 0.06 \\
1.26 & \pm 0.99 \\
0.74 & \pm 0.47 \\
16.67 & \pm 19.10 \\
1.64 & \pm 0.19 \\
0.37 & \pm 0.05\end{aligned}$ & $\begin{aligned} 22.1 & \pm 0.2 \\
34.3 & \pm 0.0 \\
7.52 & \pm 0.01 \\
2607.3 & \pm 33.7 \\
711.3 & \pm 67.1 \\
2553.2 & \pm 35.0 \\
1782.2 & \pm 49.1 \\
2420.5 & \pm 33.7 \\
78.1 & \pm 1.5 \\
1.23 & \pm 0.02 \\
1.88 & \pm 0.04 \\
0.41 & \pm 0.83 \\
0.18 & \pm 0.31 \\
1.87 & \pm 2.41 \\
0.86 & \pm 0.59 \\
1.04 & \pm 0.10\end{aligned}$ \\
\hline $25^{\circ} \mathrm{C}$ & 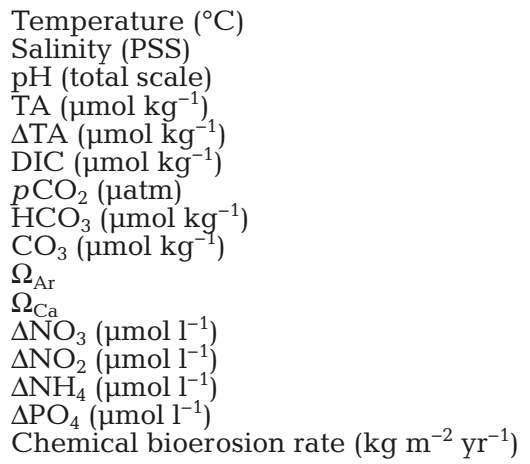 & $\begin{aligned} 23.9 & \pm 0.2 \\
34.3 & \pm 0.1 \\
8.04 & \pm 0.00 \\
2317.9 & \pm 8.2 \\
178.0 & \pm 13.4 \\
2031.8 & \pm 6.3 \\
418.2 & \pm 2.6 \\
1814.0 & \pm 5.0 \\
205.7 & \pm 1.8 \\
3.27 & \pm 0.03 \\
4.98 & \pm 0.04 \\
1.16 & \pm 0.36 \\
0.90 & \pm 0.14 \\
35.88 & \pm 31.10 \\
2.25 & \pm 0.85 \\
0.21 & \pm 0.04\end{aligned}$ & $\begin{aligned} 24.5 & \pm 0.2 \\
34.3 & \pm 0.0 \\
7.84 & \pm 0.01 \\
2414.1 & \pm 9.8 \\
368.0 & \pm 22.9 \\
2221.5 & \pm 12.9 \\
742.2 & \pm 21.7 \\
2050.5 & \pm 14.3 \\
150.0 & \pm 2.5 \\
2.39 & \pm 0.04 \\
3.63 & \pm 0.06 \\
0.75 & \pm 0.59 \\
0.94 & \pm 0.29 \\
20.96 & \pm 11.47 \\
2.58 & \pm 0.95 \\
0.51 & \pm 0.04\end{aligned}$ & $\begin{aligned} 24.5 & \pm 0.2 \\
34.3 & \pm 0.0 \\
7.57 & \pm 0.01 \\
2614.0 & \pm 25.3 \\
766.5 & \pm 41.6 \\
2526.3 & \pm 26.2 \\
1594.7 & \pm 53.5 \\
2384.7 & \pm 25.7 \\
96.3 & \pm 3.1 \\
1.54 & \pm 0.05 \\
2.33 & \pm 0.08 \\
1.23 & \pm 0.55 \\
0.97 & \pm 0.13 \\
29.90 & \pm 21.87 \\
1.99 & \pm 0.97 \\
1.09 & \pm 0.04\end{aligned}$ \\
\hline $28^{\circ} \mathrm{C}$ & 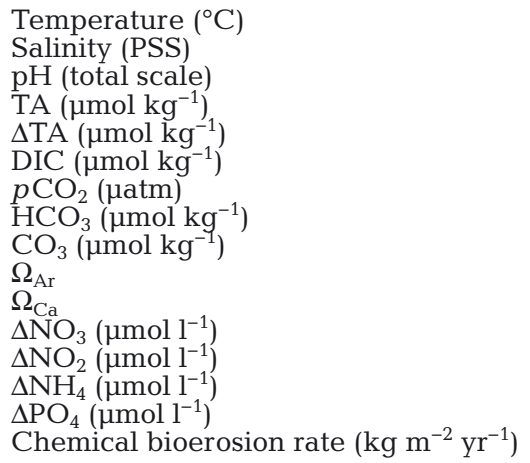 & $\begin{aligned} 27.8 & \pm 0.3 \\
34.3 & \pm 0.0 \\
8.03 & \pm 0.02 \\
2283.2 & \pm 10.0 \\
90.7 & \pm 19.4 \\
1973.4 & \pm 21.8 \\
418.9 & \pm 28.8 \\
1741.4 & \pm 28.8 \\
221.0 & \pm 8.0 \\
3.58 & \pm 0.13 \\
5.39 & \pm 0.19 \\
1.06 & \pm 0.77 \\
1.51 & \pm 0.12 \\
31.98 & \pm 30.48 \\
1.61 & \pm 1.24 \\
0.09 & \pm 0.02\end{aligned}$ & $\begin{aligned} 27.9 & \pm 0.3 \\
34.3 & \pm 0.0 \\
7.81 & \pm 0.02 \\
2359.0 & \pm 20.7 \\
238.5 & \pm 41.9 \\
2157.2 & \pm 26.5 \\
773.8 & \pm 42.9 \\
1981.8 & \pm 29.0 \\
155.2 & \pm 4.6 \\
2.52 & \pm 0.08 \\
3.78 & \pm 0.11 \\
2.06 & \pm 0.83 \\
1.99 & \pm 0.75 \\
70.90 & \pm 5.25 \\
1.76 & \pm 0.63 \\
0.25 & \pm 0.06\end{aligned}$ & $\begin{aligned} 27.9 & \pm 0.3 \\
34.3 & \pm 0.0 \\
7.55 & \pm 0.02 \\
2583.5 & \pm 20.2 \\
676.2 & \pm 23.7 \\
2487.5 & \pm 14.0 \\
1676.8 & \pm 67.1 \\
2342.9 & \pm 11.6 \\
100.9 & \pm 4.6 \\
1.64 & \pm 0.08 \\
2.46 & \pm 0.11 \\
2.07 & \pm 0.75 \\
1.87 & \pm 0.49 \\
29.39 & \pm 39.83 \\
0.97 & \pm 0.63 \\
0.95 & \pm 0.08\end{aligned}$ \\
\hline $31^{\circ} \mathrm{C}^{\mathrm{a}}$ & 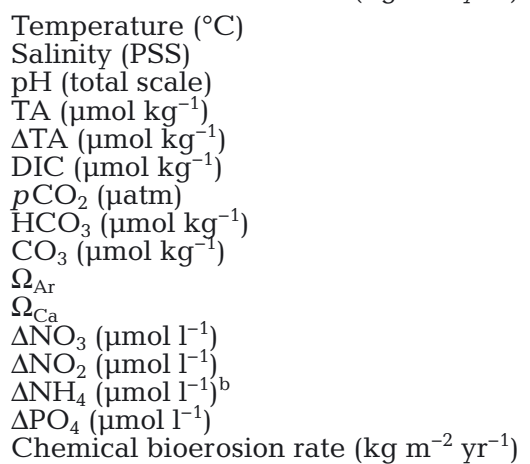 & $\begin{aligned} 30.9 & \pm 0.1 \\
34.8 & \pm 0.0 \\
8.07 & \pm 0.01 \\
2350.2 & \pm 16.9 \\
180.7 & \pm 23.4 \\
1974.6 & \pm 24.1 \\
380.0 & \pm 21.4 \\
1699.2 & \pm 27.6 \\
266.0 & \pm 4.1 \\
4.36 & \pm 0.07 \\
6.50 & \pm 0.10 \\
0.90 & \pm 0.02 \\
2.03 & \pm 0.41 \\
98.94 & \pm 0.82 \\
1.76 & \pm 0.90 \\
0.13 & \pm 0.03\end{aligned}$ & $\begin{aligned} 30.8 & \pm 0.1 \\
34.9 & \pm 0.0 \\
7.92 & \pm 0.01 \\
2403.7 & \pm 13.4 \\
279.9 & \pm 33.2 \\
2120.4 & \pm 8.9 \\
598.6 & \pm 8.8 \\
1897.3 & \pm 6.6 \\
208.3 & \pm 3.8 \\
3.41 & \pm 0.06 \\
5.08 & \pm 0.09 \\
1.69 & \pm 1.00 \\
2.15 & \pm 0.39 \\
97.93 & \pm 2.36 \\
2.29 & \pm 1.61 \\
0.28 & \pm 0.05\end{aligned}$ & $\begin{aligned} 30.8 & \pm 0.1 \\
34.9 & \pm 0.0 \\
7.56 & \pm 0.01 \\
2705.9 & \pm 86.7 \\
900.7 & \pm 171.1 \\
2581.5 & \pm 86.5 \\
1710.8 & \pm 65.2 \\
2417.4 & \pm 82.5 \\
122.1 & \pm 2.4 \\
2.00 & \pm 0.04 \\
2.98 & \pm 0.06 \\
0.15 & \pm 0.21 \\
1.92 & \pm 0.11 \\
99.73 & \pm 0.38 \\
2.43 & \pm 1.82 \\
1.18 & \pm 0.25\end{aligned}$ \\
\hline
\end{tabular}


Tables 2, S1 \& S2), no clear relationship with temperature could be demonstrated, also evidenced by only few and weakly significant differences found when testing temperature levels pairwise against each other (Fig. 4j, Tables 2, S1 \& S2). The weaker and somewhat inconclusive temperature effect was confirmed by the multiple linear regressions yielding a clear significance for the factor $p \mathrm{CO}_{2}$ and a negligible contribution of temperature (Table S2). At any given $p \mathrm{CO}_{2}$ level, bioerosion rates were highest at $25^{\circ} \mathrm{C}$ (approx. ambient winter temperature), and slightly decreased towards colder as well as towards warmer temperatures (Fig. 4j). Temperature effects on bioerosion rates were most pronounced between 25 and $28^{\circ} \mathrm{C}$, whereas for 22 and $31^{\circ} \mathrm{C}$, intermediate rates were determined (Table S1). The well-defined slopes of the linear regressions for bioerosion at different levels of $p \mathrm{CO}_{2}$ were nearly identical for 22, 25, 28 , and $31^{\circ} \mathrm{C}$, which again shows the low impact of

Table 2. PERMANOVAs with Type III sums of squares and 9999 permutations of residuals for the dependent variables health score, photosynthetic efficiency $\left(F_{\mathrm{v}} / F_{\mathrm{m}}\right)$, chlorophyll concentration $\left(F_{0}\right)$, chemical bioerosion rate, and $\Delta \mathrm{NH}_{4}$, with fixed effects, 3 levels for carbon dioxide partial pressure $\left(p \mathrm{CO}_{2}\right)$, and 4 for temperature $(\mathrm{T})$. Significant values in bold

\begin{tabular}{|c|c|c|c|c|c|c|}
\hline $\begin{array}{l}\text { Source of } \\
\text { variation }\end{array}$ & df & SS & MS & Pseudo- $F$ & $\begin{array}{c}p \\
\text { (perm) }\end{array}$ & $\begin{array}{l}\text { Unique } \\
\text { perm }\end{array}$ \\
\hline \multicolumn{7}{|c|}{ Health score (\% of 'before' values) } \\
\hline$p \mathrm{CO}_{2}$ & 2 & 163.9 & 82.0 & 0.4199 & 0.6606 & 9953 \\
\hline $\mathrm{T}$ & 3 & 20272.0 & 6757.3 & 34.6160 & 0.0001 & 9957 \\
\hline$p \mathrm{CO}_{2} \times \mathrm{T}$ & 6 & 1203.3 & 200.6 & 1.0273 & 0.4298 & 9948 \\
\hline Residual & 36 & 7027.5 & 195.2 & & & \\
\hline Total & 47 & 28667.0 & & & & \\
\hline \multicolumn{7}{|c|}{$F_{\mathrm{v}} / F_{\mathrm{m}}(\% \text { of 'before' values })^{\mathrm{a}}$} \\
\hline$p \mathrm{CO}_{2}$ & 2 & 4.0 & 2.0 & 1.3826 & 0.2655 & 9959 \\
\hline $\mathrm{T}$ & 3 & 593.4 & 197.8 & 136.1600 & 0.0001 & 9949 \\
\hline$p \mathrm{CO}_{2} \times \mathrm{T}$ & 6 & 19.6 & 3.3 & 2.2476 & 0.0621 & 9948 \\
\hline Residual & 31 & 45.0 & 1.5 & & & \\
\hline Total & 42 & 641.0 & & & & \\
\hline \multicolumn{7}{|c|}{$F_{0}(\% \text { of 'before' values })^{\mathrm{a}}$} \\
\hline$p \mathrm{CO}_{2}$ & 2 & 36.5 & 18.2 & 1.3 & 0.2995 & 9952 \\
\hline $\mathrm{T}$ & 3 & 2390.3 & 796.8 & 55.8 & 0.0001 & 9935 \\
\hline$p \mathrm{CO}_{2} \times \mathrm{T}$ & 6 & 260.8 & 43.5 & 3.0 & 0.0191 & 9930 \\
\hline Residual & 31 & 442.7 & 14.3 & & & \\
\hline Total & 42 & 3201.6 & & & & \\
\hline \multicolumn{7}{|c|}{ Chemical bioerosion rate $\left(\mathrm{kg} \mathrm{m}^{-2} \mathrm{yr}^{-1}\right)^{\mathrm{a}}$} \\
\hline$p \mathrm{CO}_{2}$ & 2 & 6.0 & 3.0 & 597.8 & 0.0001 & 9961 \\
\hline $\mathrm{T}$ & 3 & 0.2 & 0.1 & 11.7 & 0.0001 & 9951 \\
\hline$p \mathrm{CO}_{2} \times \mathrm{T}$ & 6 & 0.1 & 0.0 & 3.2 & 0.0132 & 9949 \\
\hline Residual & 31 & 0.2 & 0.0 & & & \\
\hline Total & 42 & 6.7 & & & & \\
\hline \multicolumn{7}{|c|}{$\left.\Delta \mathrm{NH}_{4}(\mu \mathrm{mol} \mathrm{l})^{-1}\right)^{\mathrm{a}}$} \\
\hline$p \mathrm{CO}_{2}$ & 2 & 1129.8 & 564.9 & 1.2 & 0.3131 & 9945 \\
\hline $\mathrm{T}$ & 3 & 27577.0 & 9192.5 & 19.5 & 0.0001 & 9947 \\
\hline$p \mathrm{CO}_{2} \times \mathrm{T}$ & 6 & 3930.1 & 655.0 & 1.4 & 0.2456 & 9955 \\
\hline Residual & 31 & 14604.0 & 471.1 & & & \\
\hline Total & 42 & 48357.0 & & & & \\
\hline
\end{tabular}

temperature (Fig. 5a-d). Based on the very well supported results of the multiple linear regression, and the fact that the overall equation is very clearly driven by $p \mathrm{CO}_{2}$, rather than temperature (Fig. $5 \mathrm{e}$, Table S2), equations for chemical sponge bioerosion rates with respect to $p \mathrm{CO}_{2}$ (Eq. 2) and to $\mathrm{pH}$ (Eq. 3) were derived from this, complemented by a regression expressing the \% increase relative to the present-day $\mathrm{pCO}_{2}$ (Eq. 4):

Chemical bioerosion rate $\left(\mathrm{kg} \mathrm{m}^{-2} \mathrm{yr}^{-1}\right)=$

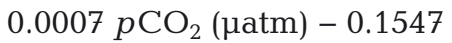

Chemical bioerosion rate $\left(\mathrm{kg} \mathrm{m}^{-2} \mathrm{yr}^{-1}\right)=$ $-1.8665 \mathrm{pH}+15.082$

Chemical bioerosion (\% of present-day rate $)=$ $0.5989 \mathrm{pCO}_{2}(\mu \mathrm{atm})-130.79$

The latter equation was applied for plotting the percent increase in chemical sponge bioerosion for 3 of the Special Report on Emissions Scenarios (SRES) as illustrated in Fig. 6. Keeping methodological differences in mind (see 'Discussion'), a comparison of the regression for total Cliona orientalis bioerosion (data from Wisshak et al. 2012) with the chemical bioerosion rates reported herein allows a tentative deduction of the ratio between chemical and mechanical bioerosion and its change with increasing $p \mathrm{CO}_{2}$ (Fig. 7). While under present-day conditions apparently only $9.2 \%$ of the substrate was removed by chemical dissolution, this fraction almost tripled to $26.5 \%$ at $1500 \mu$ atm $p \mathrm{CO}_{2}$.

\section{DISCUSSION}

\section{General conclusions relating to the experimental conditions}

We were able to show that, despite conducting the experiment in continuous darkness, the photosymbiotic sponge Cliona orientalis was not impaired for the short duration of the experiment. Zooxanthellae were shifted deeper into the sponge in darkness, as was expected (Schönberg \& Suwa 2007), but this process was not uniform across treatment temperatures. Monitoring its visual appearance and the photosynthetic parameters $F_{\mathrm{v}} / F_{\mathrm{m}}$ and $F_{0}$ demonstrated 
a

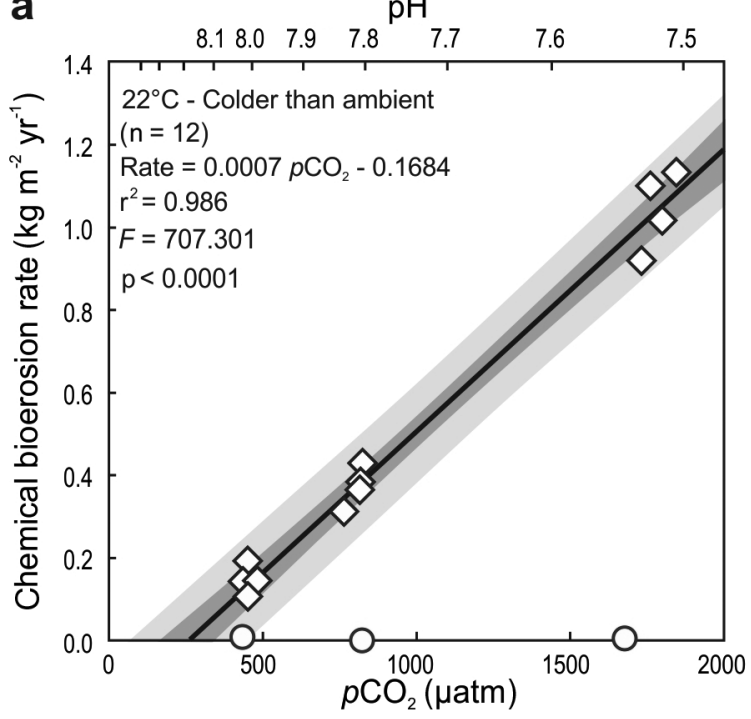

C

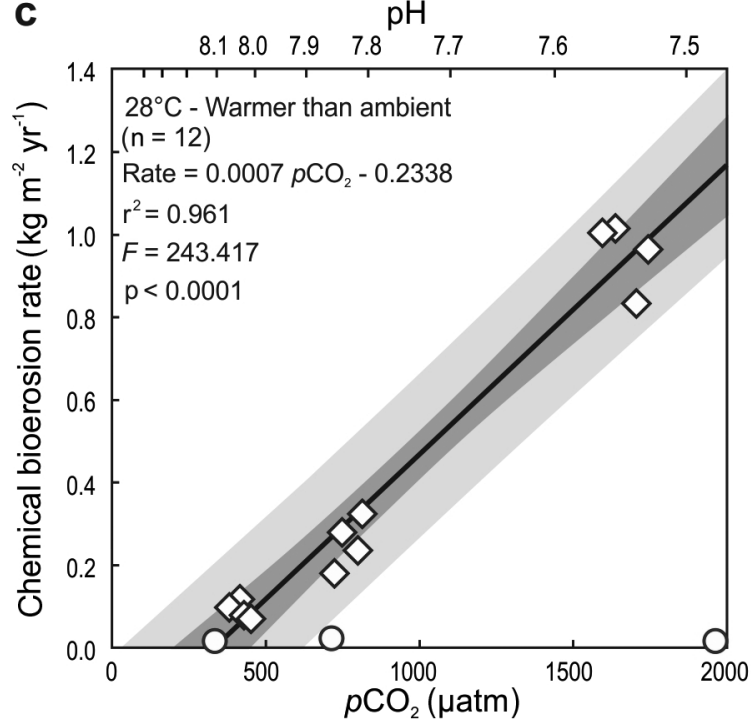

$\mathbf{e}$

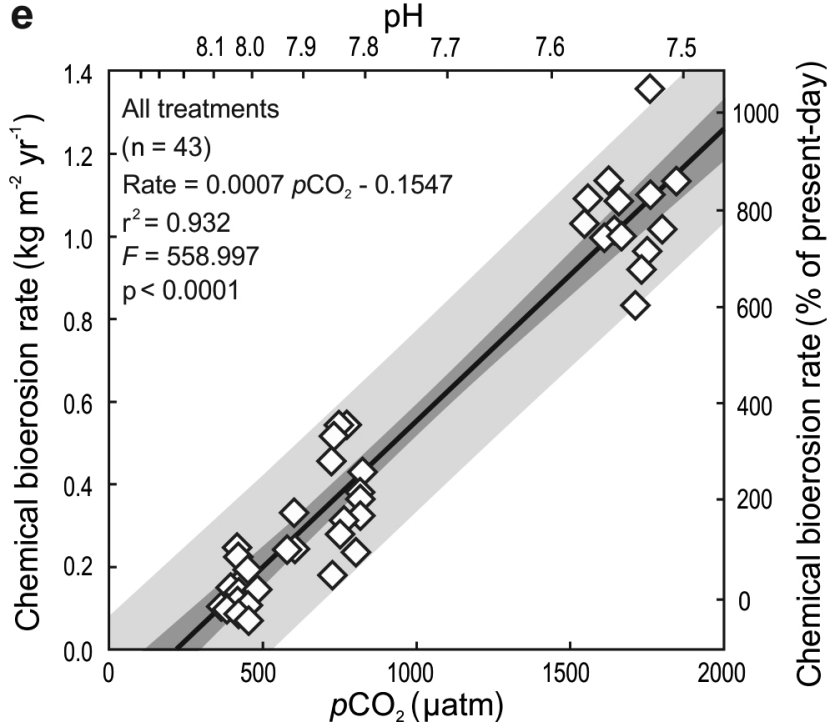

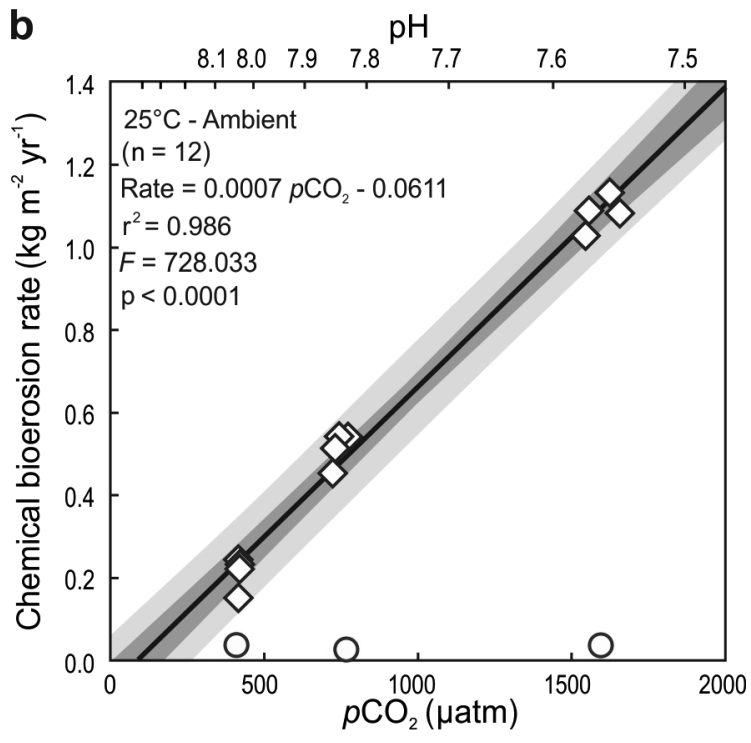

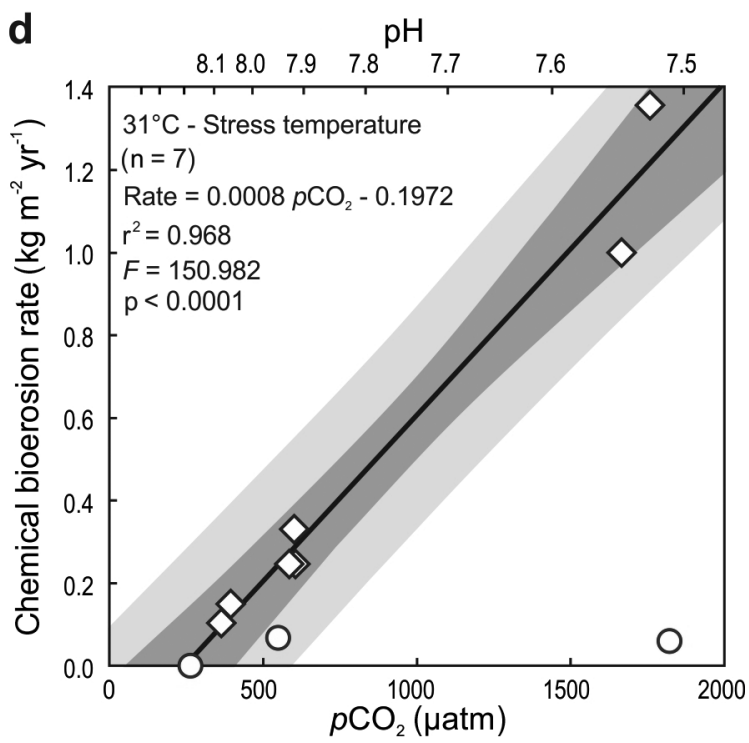

$\diamond$ Replicate (beaker with 8 sponge-bearing cores)

Blanks (beaker with seawater only)

$95 \%$ Confidence band

$95 \%$ Prediction band

Fig. 5. Rates of chemical bioerosion per replicate bioreactor as a function of $p \mathrm{CO}_{2}$ levels (present-day, moderately elevated, strongly elevated), and for the various temperature settings, with (a) $\sim 22^{\circ} \mathrm{C}$ (colder than ambient), (b) $\sim 25^{\circ} \mathrm{C}$ (ambient), (c) $\sim 28^{\circ} \mathrm{C}$ (warmer than ambient), (d) $\sim 31^{\circ} \mathrm{C}$ (stress temperature; representing only replicates without mortality), and (e) all treatments including the percent change relative to the present-day rates (blanks omitted). Linear regressions are plotted with $95 \%$ confidence and prediction bands and are highly significant for all treatments 
that while photosynthetic efficiency was temporarily reduced in cores in the $31^{\circ} \mathrm{C}$ treatment (Tables 1,2 \& S1), and health appearance and chlorophyll concentrations decreased with increasing temperature (Figs. 3 \& 4, Tables 1, 2 \& S1), all surviving cores quickly recovered to their original appearance under flow-through/ambient conditions after the experi-

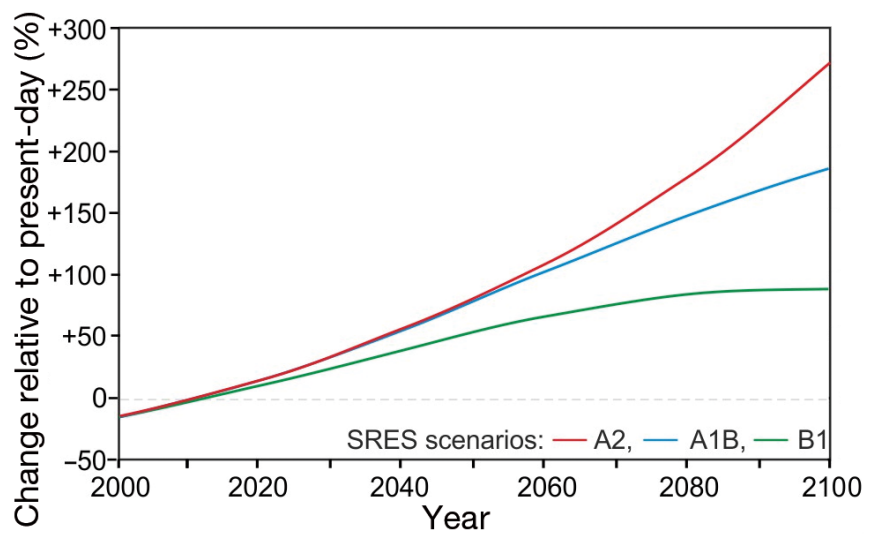

Fig. 6. Projected percent increase in chemical sponge bioerosion relative to the present-day level, calculated for the BERN-CC model based on the Special Report on Emissions

Scenarios (SRES) A2 (red), A1B (blue), and B1 (green)

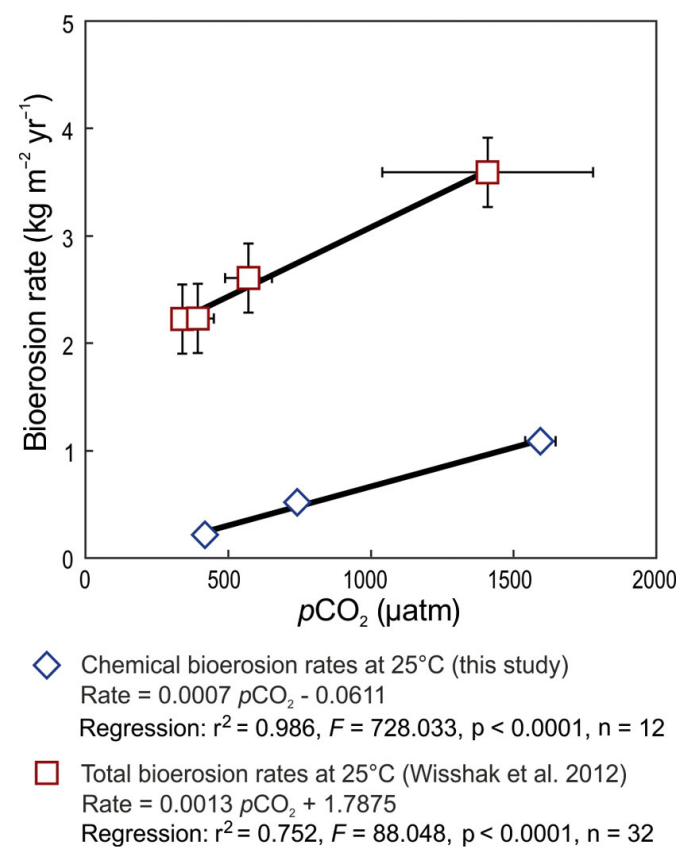

Fig. 7. Chemical bioerosion rates from the present study's $25^{\circ} \mathrm{C}$ treatment compared to the $25^{\circ} \mathrm{C}$ total bioerosion rates reported by Wisshak et al. (2012). The significant increase in total bioerosion rates is to a large extent governed by the increase in chemical bioerosion, while mechanical bioerosion increases only slightly. The fraction of chemical versus total bioerosion increases from $1 / 10$ at $390 \mu$ atm to $1 / 5$ at $1000 \mu \mathrm{atm}$ and $1 / 4$ at $1500 \mu \mathrm{atm}$ ment (Fig. 3b). While strongly increased temperature apparently had a negative effect on the sponge's health and on the photosynthesis of its symbionts, $p \mathrm{CO}_{2}$ did not (Tables $2 \& \mathrm{~S} 1$ ), or might even have had a slightly ameliorating effect on the temperature stress, a hypothesis which may be supported by interaction effects between temperature and $p \mathrm{CO}_{2}$ found near the significance level (Fig. 4c, Table 2). The effects of $p \mathrm{CO}_{2}$ on bioerosion can thus be identified as direct effects and were not caused by indirect impacts through lowered fitness.

The experimentally determined carbonate dissolution can be assigned with confidence to chemical bioerosion by Cliona orientalis. In all 12 settings of the $p \mathrm{CO}_{2} \times$ temperature treatment matrix, the culture seawater was saturated with respect to both aragonite and calcite $(\Omega>1$; Table 1$)$, even under conditions where the lowest saturation state would be expected, i.e. the $22^{\circ} \mathrm{C}$ treatment with strongly elevated $p \mathrm{CO}_{2}$. In order to maintain a stable $\mathrm{pH}$ and saturation regime without a diurnal rhythmicity induced by $\mathrm{CO}_{2}$ uptake during photosynthesis of the photosymbionts and by increasing temperatures during the illumination phase, such as recorded by Wisshak et al. (2012), the experiment was run in constant darkness. Therefore, our bioerosion values may be underestimations, because zooxanthellate clionaids receive supplementing nutrients from their symbionts, and over longer periods erode more in light than in shade (Schönberg 2006 and references therein, Weisz et al. 2010). However, over a short period of only few days, this would not significantly affect bioerosion, as filter-feeding was not impaired, and clionaids are also known to assimilate dissolved nutrients from the water column (Maldonado et al. 2012). Moreover, clionaids may switch their symbiotic relationships depending on circumstances and digest zooxanthellae (Rosell 1993, Hill \& Hill 2012). We would expect a lag period before physiological functions would be affected by the missing addition from the symbionts. A potential contribution of nonsponge endoliths to the recorded bioerosion in the coral cores that would have led to overestimated sponge bioerosion rates was assumed negligible based on the observation that substrate occupied by C. orientalis is not usually infested by other macroborers. Moreover, the overlying sponge tissue apparently prevents establishment of a significant microendolith community (coral matrix and potential microendoliths $=$ mass of organics in coral substrate made up less than 1\%; Fang et al. 2013). Important additional support for reporting unbiased sponge bioerosion is provided by the fact that control cores in a 
previous experiment did not lose weight during $10 \mathrm{~d}$ of exposure (Wisshak et al. 2012). While bacterial bioerosion in the $31^{\circ} \mathrm{C}$ treatment cannot be discounted, tissue death only occurred late in the experiment, thus only allowing a short period for bias, and apart from that, bioreactors with dead sponges were excluded from the calculations for bioerosion. We furthermore ruled out unrelated shifts in the carbonate system of the culture seawater by monitoring bioreactor blanks that did not contain any sponge or coral material, none of which exhibited a relevant $\Delta$ TA over the course of the experiment (Fig. 5a-d). Hence, the positive $\Delta$ TA in the bioreactors containing sponge cores is interpreted to be caused solely by chemical sponge bioerosion.

\section{Influence of temperature and $p \mathrm{CO}_{2}$ on sponge bioerosion}

Temperature effects on Cliona orientalis bioerosion rates did not follow a clear linear trend in our experiment (Fig. 4j, Table S2) and may in part also reflect effects of the ammonium building up. The highest bioerosion rates were reached at the local ambient temperature of $25^{\circ} \mathrm{C}$, decreasing towards colder as well as warmer temperatures. Overall, the influence of temperature on the bioerosion capacity of $C$. orientalis appears to be very low to negligible despite other physiological responses caused by heat (Fig. 4, Tables 1, 2, S1 \& S2), particularly with respect to ammonium, that can be interpreted as a sign of excretion and/or disintegrative processes (Wright 1995, Francis-Floyd et al. 2009). The observed significant positive correlation of ammonium with temperature (Table 2) likely suggests increasing heat stress, with resulting ammonium and/or ammonia potentially acting as an additional indirect stressor (Bower \& Bidwell 1978, Osinga et al. 1999). In contrast to temperature, $p \mathrm{CO}_{2}$ does not correlate with the observed ammonium levels (Table 2). However, high $\mathrm{pH}$ favours the formation of the more toxic ammonia (Osinga et al. 1999), which may partly explain the slightly more negative response in the low- $p \mathrm{CO}_{2}$ treatments (Fig. 4). Little is known about the rate of ammonium/ammonia generation and tolerance in sponges (Osinga et al. 1999). According to Sipkema et al. (2004), isolated cells of the Mediterranean demosponge Suberites domuncula (Olivi, 1792) were not affected by very high ammonium treatments (up to $25000 \mathrm{\mu mol} \mathrm{l}^{-1}$; compared to our maximum of 100 $\mu \mathrm{mol} \mathrm{l}^{-1}$ ), but were clearly negatively affected by heat $\left(12\right.$ to $\left.28^{\circ} \mathrm{C}\right)$. Moreover, the sponge samples originated from a coastal reef that is subject to large fluctuations of seasonal and disturbance-related water quality (e.g. Fabricius \& Dommisse 2000); however, they are very successful at this site (Schönberg \& Ortiz 2009). We thus regard the overall effect of ammonium as smaller than the heat treatment. While the increase of ammonium levels across the temperature treatments was significant, the concentrations alone may not have been high enough to cause the observed mortality, but the strongly elevated ammonium in the $31^{\circ} \mathrm{C}$ treatment may well be a result of tissue death towards the end of the experiment.

Sponge cores that survived the stress temperature yielded comparatively high bioerosion rates. Nevertheless, critically high sea surface temperatures may harm bioeroders to a similar degree as calcifiers and may trigger diseases, reduction in symbiont viability, and mortality in both organism guilds (Osinga et al. 1999, Schönberg et al. 2008).

Temperature having little influence on sponge bioerosion rates was surprising and could possibly be explained by 3 partly antagonistic processes:

(1) Acceleration of biochemical processes with increasing temperature may lead to increased rates of chemical bioerosion within metabolic tolerance limits (van't Hoff equation and its derivations: 2 to $4 \times$ reaction speed with every $10^{\circ} \mathrm{C}$ increase; $Q_{10}$ factor $>1$; Atkins \& De Paula 2009).

(2) Rising temperatures will reduce the physicochemical dissolution capacity of $\mathrm{CaCO}_{3}$ in seawater (Mehrbach et al. 1973) and may thus decrease bioerosion capabilities.

(3) Metabolic processes inherent to Cliona orientalis may function best at local ambient temperature the sponge is adapted to.

Options (1) and (2) may cancel each other out to some degree, but will only function within the limits of (3). The latter would also explain the observation of most pronounced bioerosion recorded at ambient conditions, because re-adaption to colder or warmer temperatures may cost energy and thus lead to a temporary loss in bioerosion efficiency as a trade-off.

Our observation of temperature having little or possibly a non-linear effect on bioerosion rates was most recently confirmed for a related species, Cliona cf. celata Grant, 1826 (explants on scallop shells; Duckworth \& Peterson 2013). The latter authors found no significant relationship between shell weight loss and temperature, using $26^{\circ} \mathrm{C}$ as an ambient setting and $31^{\circ} \mathrm{C}$ for the year 2100 .

Cliona orientalis chemical bioerosion rates consistently and significantly increased with increasing $p \mathrm{CO}_{2}$, and the present observations are thus in good 
accordance with earlier findings on total sponge bioerosion of the same species (Wisshak et al. 2012), as well as that of the related C. cf. celata (Duckworth \& Peterson 2013; acid-regulated experiment with bioerosion rates doubling from $\mathrm{pH} 8.1$ to 7.8 ). This clearly confirms our initial hypothesis that sponge bioerosion can be predicted to escalate with progressing OA. Applying Eq. (4), the increase of chemical bioerosion by $C$. orientalis converts to a $268.3 \%$ escalation by the end of this century, following the BERN-CC model based on the Special Report on Emissions Scenarios (SRES) A2 emission scenario (2100 $p \mathrm{CO}_{2}=836 \mu \mathrm{atm}$; IPCC 2001). The most optimistic B1 model $\left(p \mathrm{CO}_{2}=540 \mu \mathrm{atm}\right)$ would lead to a $91.0 \%$ increase in $C$. orientalis chemical bioerosion, and the moderate A1B model $\left(p \mathrm{CO}_{2}=703 \mu \mathrm{atm}\right)$ to an elevation of $185.2 \%$ (Fig. 6). The observed rise in chemical bioerosion is one order in magnitude stronger than for total bioerosion of $C$. orientalis as predicted by Wisshak et al. (2012; compare to Fig. 5b therein). Predictions based on the Representative Concentration Pathways (RCPs; Meinshausen et al. 2011) - a set of 4 scenarios for use in climate modellingresult in similar figures of $86.5,164.1$, and $320.6 \%$ increase in $C$. orientalis chemical bioerosion for the RCP $4.5\left(2100 p \mathrm{CO}_{2}=538 \mu \mathrm{atm}\right), 6\left(p \mathrm{CO}_{2}=\right.$ $670 \mu \mathrm{atm})$, and $8.5\left(\mathrm{CO}_{2}=936 \mu \mathrm{atm}\right)$ scenarios, respectively. Hence, doubling to quadrupling of chemical bioerosion by $C$. orientalis can be expected by the year 2100, depending on which emission scenario is considered. At the same time, according to the IPCC (2001), surface air temperatures are expected to rise by $1.98^{\circ} \mathrm{C}$ (SRES B1 model) to $3.79^{\circ} \mathrm{C}$ (A2 model), which may push many tropical coral reefs into a temperature range where bioeroding sponges may be seasonally exposed to heat stress and possibly to mortality, thus limiting the range of the $p \mathrm{CO}_{2}$ effect on reef bioerosion.

Sponge bioerosion is therefore much more clearly and strongly influenced by $p \mathrm{CO}_{2}$ than by temperature, and follows a directly proportional, linear trend for $p \mathrm{CO}_{2}$, while the response to temperature and/or ammonium is more complicated. Temperature may cause a threshold response with respect to the sponge's physiology, and bioerosion ceases when other physiological functions are impaired. In contrast, the relationship between $p \mathrm{CO}_{2}$ and sponge bioerosion may act along 2 pathways: the acceleration of chemical bioerosion by lowering the $\mathrm{pH}$ gradient that needs to be overcome in the related biochemical reaction (Wisshak et al. 2012), and the enhancement of the sponges' energy budget by translocation of carbon stemming from the photosymbionts (Weisz et al.
2010), a process that may be facilitated by OA, not inhibiting the sponge's physiology.

Considering the important role of bioeroding sponges for reef carbonate budgets (e.g. Acker \& Risk 1985, Schönberg 2002b, Nava \& Carballo 2008, Perry et al. 2008), observations that their abundances increased after disturbance and stress (e.g. Rützler 2002, Ward-Paige et al. 2005, Schönberg \& Ortiz 2009), the fact that other organisms using chemical bioerosion exhibited similar trends in climate change studies (Tribollet et al. 2006, 2009, Reyes-Nivia et al. 2013), and that advanced internal bioerosion facilitates external bioerosion by grazers (e.g. Tribollet et al. 2011), we fully expect that total bioerosion will increase in future until the physiological limits of the involved organisms are reached. However, while short-term aquarium experiments were very conclusive with respect to the effects of $p \mathrm{CO}_{2}$ on bioerosion rates of single species or microbial communities (Tribollet et al. 2006, 2009, Wisshak et al. 2012, Reyes-Nivia et al. 2013), we only have very little evidence from natural environments at the community level and over longer periods of time (but see e.g. Fabricius et al. 2011). Therefore, further studies are required to understand future trends of bioerosion in a larger context and how they will affect reef carbonate budgets in different environments.

\section{Chemical versus mechanical bioerosion in Cliona orientalis}

Sponge bioerosion is a process involving chemical etching that leads to the mechanical removal of sponge chips which are then expelled (e.g. Schönberg 2008). Compared to our value of $9 \%$ chemical bioerosion in Cliona orientalis, a considerable range of ratios between contributions of chemical and mechanical sponge bioerosion have been reported in the literature. Warburton (1958) estimated that $<10 \%$ of carbonate is dissolved by Cliona cf. celata from Eastern Canada. Based on SEM analyses studying Pione lampa (de Laubenfels, 1950) from Bermuda, Rützler \& Rieger (1973) calculated that only 2 to $3 \%$ of the carbonate goes into solution, which is the lowest rate reported to date. Zundelevich et al. (2007) simultaneously measured chemical and mechanical erosion in Red Sea Pione cf. vastifica (Hancock, 1849), and found that chemical dissolution was the dominant mode of bioerosion, contributing $75 \%$ to the total rate. More recently, Nava \& Carballo (2008) refined the method introduced by Zundelevich et al. 
(2007), and quantified chemical bioerosion at $29 \%$ in the Mexican Pacific Cliona vermifera Hancock, 1867 , and $12 \%$ in Cliona flavifodina Rützler, 1974, respectively. We argue that the strong variation in the contribution of chemical dissolution may partly be influenced by the $\mathrm{pH}$ of the surrounding water, considering that according to Doney (2006), the 2 sites with the experimentally determined highest ratios of chemical bioerosion - the Red Sea and the Mexican Pacific (Zundelevich et al. 2007, Nava \& Carballo 2008) - have comparatively acidic seawater (ca. pH 7.9 according to Doney 2006), while the classic studies with low ratios of chemical bioerosion were conducted in less acidic areas (Warburton 1958, Rützler \& Rieger 1973; around pH 8.1 according to Doney 2006). This theory may be supported by observations by Schönberg (2008), who noticed significant differences in sponge scar morphologies comparing the width of the groove etched to remove the sponge chips.

As for Cliona orientalis, the increase in the chemical bioerosion rate with increasing $p \mathrm{CO}_{2}$ is much more pronounced than the increase of total bioerosion determined for the same species and under similar experimental conditions (see Fig. 5 in Wisshak et al. 2012). This is, however, not a contradiction, but merely the reflection of a shift in the contribution of chemical versus mechanical mode of sponge bioerosion. Keeping in mind that our earlier experiment (Wisshak et al. 2012) was conducted in a light/dark setting over a longer period of time and in a flowthrough situation, the marked difference in the slopes of the increased bioerosion capacities relative to a change in $p \mathrm{CO}_{2}$ is not affected by experimental differences, and thus suggests that it is primarily the chemical bioerosion that increases. It is not surprising that it is the chemical etching which is directly affected by a more acidic environment, because the process is acting at the cell-substrate interface, where ambient conditions have to be overcome. Mechanical bioerosion remained comparatively constant with $p \mathrm{CO}_{2}$ as evidenced by the nearly constant vertical offset between the 2 regressions in Fig. 7, but the absolute ratio of mechanical versus chemical erosion needs to be interpreted with caution when comparing the 2 separate experiments (see 'Results: Bioerosion rates').

While an increase in etching efficiency with increased $p \mathrm{CO}_{2}$ would be expected to result in the mechanical liberation of proportionally more sponge chips, a different effect comes into play: our data suggest that not only will the number of sponge chips be increasing, but a substantial part of the enforced etching capacity may be directed towards an increase in the width of the etching grooves (i.e. the etched crevice between the substrate and the chip), resulting in a reduced size of the chips under more acidic conditions, if assuming that maximum chip diameter is restricted by cell properties (Rützler \& Rieger 1973). Therefore, while global warming may have little effect within the physiological tolerance limits of the sponges, OA will significantly accelerate their bioerosion rates, which we hypothesise will lead to only a slight increase in the production of sponge-generated sediment and a reduction in grain size.

Acknowledgements. Fieldwork at Orpheus Island was only possible with the supreme logistic support of various AIMS staff members including M. Donaldson and D. Stockham, and the OIRS team S. Kelly, H. Burgess, P. Lawn, R. Wiley, and P. Costello, and greatly profited from the commitment of the scientific volunteers R. and D. Wisdom, G. Ford, and A. Ulrich. Statistical analyses significantly benefitted from advice provided by K. Murray, J. Russel, and M. Thums, University of Western Australia, and M. Carreiro-Silva, University of the Azores. We are indebted to the thorough indepth reviews provided by the anonymous referees. This study was financially supported by the Deutsche Forschungsgemeinschaft (Grant Fr 1134/19), co-funded by the AIMS.

\section{LITERATURE CITED}

Acker KL, Risk MJ (1985) Substrate destruction and sediment production by the boring sponge Cliona caribbaea on Grand Cayman Island. J Sediment Petrol 55:705-711

Anderson MJ (2005) PERMANOVA: a FORTRAN computer program for permutational multivariate analysis of variance. Department of Statistics, University of Auckland. www.stat.auckland.ac.nz/ mja/prog/PERMANOVA_ UserNotes.pdf

Anderson MJ, Gorley RN, Clarke KR (2008) PERMANOVA+ for PRIMER: guide to software and statistical methods. PRIMER-E, Plymouth

Andersson AJ, Mackenzie FT, Gattuso JP (2011) Effects of ocean acidification on benthic processes, organisms, and ecosystems. In: Gattuso J-P, Hansson L (eds) Ocean acidification. University Press, Oxford, p 122-153

Atkins P, De Paula J (2009) Physical chemistry, 9th edn. WH Freeman, New York, NY

Bower CE, Bidwell JP (1978) Ionization of ammonia in seawater: effects of temperature, $\mathrm{pH}$, and salinity. J Fish Res Board Can 35:1012-1016

Chisholm JRM, Gattuso JP (1991) Validation of the alkalinity anomaly technique for investigating calcification and photosynthesis in coral reef communities. Limnol Oceanogr 36:1232-1239

De'ath G, Lough JM, Fabricius KE (2009) Declining coral calcification on the Great Barrier Reef. Science 323: $116-119$

Dickson AG (1990) Standard potential of the reaction: $\mathrm{AgCl}(\mathrm{s})+1 / 2 \mathrm{H}_{2}(\mathrm{~g})=\mathrm{Ag}(\mathrm{s})+\mathrm{HCl}(\mathrm{aq})$, and the standard acidity constant of the ion $\mathrm{HSO}_{4}{ }^{-}$in synthetic seawater from 273.15 to 318.15 K. J Chem Thermodyn 22:113-127 
Dickson AG, Millero FJ (1987) A comparison of the equilibrium constants for the dissociation of carbonic acid in seawater media. Deep-Sea Res 34:1733-1743

> Dickson AG, Afghan JD, Anderson GC (2003) Reference materials for oceanic $\mathrm{CO}_{2}$ analysis: a method for the certification of total alkalinity. Mar Chem 80:185-197

Doney SC (2006) The dangers of ocean acidification. Sci Am 294:58-65

> Duckworth AR, Peterson BJ (2013) Effects of seawater temperature and $\mathrm{pH}$ on the boring rates of the sponge Cliona celata in scallop shells. Mar Biol 160:27-35

Erez J, Reynaud S, Silverman J, Schneider K, Allemand D (2011) Coral calcification under ocean acidification and global change. In: Dubinsky S, Stambler N (eds) Coral reefs: an ecosystem in transition. Springer, New York, NY, p 151-176

Fabricius KE, Dommisse M (2000) Depletion of suspended particulate matter over coastal reef communities dominated by zooxanthellate soft corals. Mar Ecol Prog Ser 196:157-167

Fabricius KE, Langdon C, Uthicke S, Humphrey C and others (2011) Losers and winners in coral reefs acclimatized to elevated carbon dioxide concentrations. Nat Clim Change 1:165-169

Fang JKH, Schönberg CHL, Kline DI, Hoegh-Guldberg O, Dove S (2013) Methods to quantify components of the excavating sponge Cliona orientalis Thiele, 1900. Mar Ecol 34:193-206

Francis-Floyd R, Watson C, Petty D, Pouder DB (2009) Ammonia in aquatic systems. \#FA16, University of Florida IFAS Extension, Gainesville, FL

Glynn PW (1997) Bioerosion and coral reef growth: a dynamic balance. In: Birkeland C (ed) Life and death of coral reefs. Chapman \& Hall, New York, NY, p 68-95

Hansen HP, Koroleff F (1999) Determination of nutrients. In: Grasshoff K, Kremling K, Ehrhardt M (eds) Methods of seawater analysis. Verlag Chemie, Weinheim, p 159-228

> Hill M, Hill A (2012) The magnesium inhibition and arrested phagosome hypotheses: new perspectives on the evolution and ecology of Symbiodinium symbioses. Biol Rev Camb Philos Soc 87:804-821

> Hoegh-Guldberg O, Mumby PJ, Hooten AJ, Steneck RS and others (2007) Coral reefs under rapid climate change and ocean acidification. Science 318:1737-1742

> Holmes RM, McClelland JW, Sigman DM, Fry B, Peterson BJ (1998) Measuring ${ }^{15} \mathrm{~N}-\mathrm{NH}_{4}{ }^{+}$in marine, estuarine and fresh waters: an adaptation of the ammonia diffusion method for samples with low ammonium concentrations. Mar Chem 60:235-243

> Hoppe CJM, Langer G, Rokitta SD, Wolf-Gladrow DA, Rost B (2012) Implications of observed inconsistencies in carbonate chemistry measurements for ocean acidification studies. Biogeosciences 9:2401-2405

IPCC (2001) Climate change 2001: the scientific basis. Contribution of Working Group I to the third assessment report of the Intergovernmental Panel on Climate Change. Cambridge University Press, Cambridge

> Jacques TG, Pilson EQ (1980) Experimental ecology of the temperate scleractinian coral Astrangia danae. I. Partition of respiration, photosynthesis and calcification between host and symbionts. Mar Biol 60:167-178

Kroeker KJ, Kordas RL, Crim RN, Singh GG (2010) Metaanalysis reveals negative yet variable effects of ocean acidification on marine organisms. Ecol Lett 13:1419-1434 Kroeker KJ, Kordas RL, Crim RN, Hendriks IE and others
(2013) Impacts of ocean acidification on marine organisms: quantifying sensitivities and interaction with warming. Global Change Biol 19:1884-1896

Lynch TC, Phlips EJ (2000) Filtration of the bloom-forming cyanobacteria Synechococcus by three sponge species from Florida Bay, USA. Bull Mar Sci 67:923-936

Maldonado M, Giraud K, Carmona C (2008) Effects of sediment on the survival of asexually produced sponge recruits. Mar Biol 154:631-641

Maldonado M, Ribes M, van Duyl FC (2012) Nutrient fluxes through sponges: biology, budgets, and ecological implications. In: Becerro MA, Uriz MJ, Maldonado M, Turon X (eds) Adv Mar Biol 62. Advances in sponge science: physiology, chemical and microbial diversity, biotechnology. Elsevier, London, p 113-182

Mehrbach C, Culberson CH, Hawley JE, Pytcowicz RM (1973) Measurement of the apparent dissociation constants of carbonic acid in seawater at atmospheric pressure. Limnol Oceanogr 18:897-907

> Meinshausen M, Smith SJ, Calvin K, Daniel JS and others (2011) The RCP greenhouse gas concentrations and their extensions from 1765 to 2300. Clim Change 109:213-241

> Nava H, Carballo JL (2008) Chemical and mechanical bioerosion of boring sponges from Mexican Pacific coral reefs. J Exp Biol 211:2827-2831

> Osinga R, Tramper J, Wijffels RH (1999) Cultivation of marine sponges. Mar Biotechnol (NY) 1:509-532

> Pandolfi JM, Connolly SR, Marshall DJ, Cohen AL (2011) Projecting coral reef futures under global warming and ocean acidification. Science 333:418-422

> Perry CT, Spencer T, Kench PS (2008) Carbonate budgets and reef production states: a geomorphic perspective on the ecological phase-shift concept. Coral Reefs 27: 853-866

Pierrot D, Lewis E, Wallace DWR (2006) MS Excel program developed for $\mathrm{CO}_{2}$ system calculations. ORNL/CDIAC105a. Carbon Dioxide Information Analysis Center, Oak Ridge National Laboratory, US Department of Energy, Oak Ridge, TN

> Reyes-Nivia C, Diaz-Pulido G, Kline D, Hoegh-Guldberg O, Dove S (2013) Ocean acidification and warming scenarios increase microbioerosion of coral skeletons. Global Change Biol 19:1919-1929

Reynaud S, Leclercq N, Romaine-Lioud S, Ferrier-Pagès C, Jaubert J, Gattuso JP (2003) Interacting effects of $\mathrm{CO}_{2}$ partial pressure and temperature on photosynthesis and calcification in a scleractinian coral. Global Change Biol 9:1660-1668

Rodolfo-Metalpa R, Houlbrèque F, Tambutté É, Boisson F and others (2011) Coral and mollusc resistance to ocean acidification adversely affected by warming. Nat Clim Change 1:308-312

Rosell D (1993) Effects of reproduction on Cliona viridis (Hadromerida) on zooxanthellae. Sci Mar 57:405-413

Rützler K (2002) Impact of crustose clionid sponges on Caribbean reef corals. Acta Geol Hisp 37:61-72

Rützler K, Rieger G (1973) Sponge burrowing: fine structure of Cliona lampa penetrating calcareous substrata. Mar Biol 21:144-162

> Schönberg CHL (2000) Bioeroding sponges common to the central Australian Great Barrier Reef: descriptions of three new species, two new records, and additions to two previously described species. Senckenb Marit 30:161-221

Schönberg CHL (2001) Small-scale distribution of Great Barrier Reef bioeroding sponges in shallow water. 
Ophelia 55:39-54

Schönberg CHL (2002a) Sponges of the 'Cliona viridis complex' - a key for species identification. Proc 9th Int Coral Reef Symp, Bali 1:295-299

Schönberg CHL (2002b) Substrate effects on the bioeroding demosponge Cliona orientalis. 1. Bioerosion rates. Mar Ecol 23:313-326

Schönberg CHL (2006) Growth and erosion of the zooxanthelate Australian bioeroding sponge Cliona orientalis are enhanced in light. Proc 10th Int Coral Reef Symp, Okinawa, p 168-174

Schönberg CHL (2008) A history of sponge erosion: from past myths and hypotheses to recent approaches. In: Wisshak M, Tapanila L (eds) Current developments in bioerosion. Springer, Heidelberg, p 165-202

Schönberg CHL, Ortiz JC (2009) Is sponge bioerosion increasing? Proc 11th Int Coral Reef Symp Fort Lauderdale, USA, p 520-523

Schönberg CHL, Shields G (2008) Micro-computed tomography for studies on Entobia: transparent substrate versus modern technology. In: Wisshak M, Tapanila L (eds) Current developments in bioerosion. Springer, Heidelberg, p 147-164

Schönberg CHL, Suwa R (2007) Why bioeroding sponges may be better hosts for symbiotic dinoflagellates than many corals. In: Custódio MR, Lôbo-Hajdu G, Hajdu E, Muricy G (eds) Porifera research: biodiversity, innovation and sustainability. Museu Nacional Rio de Janeiro, p 569-580

Schönberg CHL, Wilkinson CR (2001) Induced colonization of corals by a clionid bioeroding sponge. Coral Reefs 20: 69-76

Schönberg CHL, Suwa R, Hidaka M, Loh WKW (2008) Sponge and coral zooxanthellae in heat and light: preliminary results of photochemical efficiency monitored with pulse amplitude modulated fluorometry. Mar Ecol 29:247-258

Sipkema D, Snijders APL, Schroën CGPH, Osinga R, Wijffels RH (2004) The life and death of sponge cells. Biotechnol Bioeng 85:239-247

Smith SV, Key GS (1975) Carbon dioxide and metabolism in marine environments. Limnol Oceanogr 20:493-495

Stoll HM, Ruiz-Encinar J, Garcia-Alonso JI, Rosenthal Y, Klaas C, Probert I (2001) A first look at paleotemperature

Editorial responsibility: Paul Sammarco,

Chauvin, Louisiana, USA prospects from $\mathrm{Mg}$ in coccolith carbonate: cleaning techniques and culture measurements. Geochem Geophys Geosyst 2:1047, doi:10.1029/2000GC000144

Tribollet A, Golubic S (2011) Reef bioerosion: agents and processes. In: Dubinsky Z, Stambler N (eds) Coral reefs: an ecosystem in transition. Springer, Berlin, p 335-449

> Tribollet A, Atkinson MJ, Langdon C (2006) Effects of elevated $p \mathrm{CO}_{2}$ on epilithic and endolithic metabolism of reef carbonates. Global Change Biol 12:2200-2208

> Tribollet A, Godinot C, Atkinson M, Langdon C (2009) Effects of elevated $\mathrm{pCO}_{2}$ on dissolution of coral carbonates by microbial euendoliths. Global Biogeochem Cycles 23: 1-7, doi:10.1029/2008GB003286

Tribollet A, Radtke G, Golubic S (2011) Bioerosion. In: Reitner J, Thiel V (eds) Encyclopedia of geobiology. Springer, Berlin, p 117-134

van Soest RWM, Boury-Esnault N, Hooper JNA, Rützler K and others (2013) World Porifera Database. Available at: www.marinespecies.org/porifera

> Veron JEN (2011) Ocean acidification and coral reefs: an emerging big picture. Diversity 3:262-274

- Warburton FE (1958) The manner in which the sponge Cliona bores in calcareous objects. Can J Zool 36: 555-562

- Ward-Paige CA, Risk MJ, Sherwood OA, Jaap WC (2005) Clionid sponge surveys on the Florida Reef Tract suggest land-based nutrient inputs. Mar Pollut Bull 51: 570-579

Weisz JB, Massaro AJ, Ramsby BD, Hill MS (2010) Zooxanthellar symbionts shape host sponge trophic status through translocation of carbon. Biol Bull (Woods Hole) 219:189-197

Wisshak M, Tapanila L (2008) Current developments in bioerosion. Springer, Heidelberg

- Wisshak M, Schönberg CHL, Form A, Freiwald A (2012) Ocean acidification accelerates reef bioerosion. PLoS ONE 7:e45124

Wright P (1995) Review nitrogen excretion: three end products, many physiological roles. J Exp Biol 198:273-281

Zeebe RE, Wolf-Gladrow D (2001) $\mathrm{CO}_{2}$ in seawater: equilibrium, kinetics, isotopes. Elsevier, Amsterdam

> Zundelevich A, Lazar B, Ilan M (2007) Chemical versus mechanical bioerosion of coral reefs by boring sponges lessons from Pione cf. vastifica. J Exp Biol 210:91-96

Submitted: March 26, 2013; Accepted: July 19, 2013

Proofs received from author(s): September 12, 2013 